\title{
Hydrocarbon accumulation in basins with multiple phases of extension and inversion: examples from the Western Desert (Egypt) and the western Black Sea
}

\author{
William Bosworth ${ }^{1}$ and Gábor Tari ${ }^{2}$ \\ ${ }^{1}$ Apache Egypt Companies, 11 Street 281, New Maadi, Cairo, Egypt \\ ${ }^{2}$ OMV Upstream, Exploration, Trabrennstrasse 6-8, 1020 Vienna, Austria
}

Correspondence: William Bosworth (bill.bosworth@apacheegypt.com)

Received: 5 June 2020 - Discussion started: 30 June 2020

Revised: 2 November 2020 - Accepted: 4 November 2020 - Published: 14 January 2021

\begin{abstract}
Folds associated with inverted extensional faults are important exploration targets in many basins across our planet. A common cause for failure to trap hydrocarbons in inversion structures is crestal breaching or erosion of top seal. The likelihood of failure increases as the intensity of inversion grows. Inversion also decreases the amount of overburden, which can adversely affect maturation of source rocks within the underlying syn-extensional stratigraphic section. However, many rift basins are multi-phase in origin, and in some cases the various syn-rift and post-rift events are separated by multiple phases of shortening. When an inversion event is followed by a later phase of extension and subsidence, new top seals can be deposited and hydrocarbon maturation enhanced or reinitiated. These more complex rift histories can result in intra-basinal folds that have higher chances of success than single-phase inversion-related targets. In other basins, repeated inversion events can occur without significant intervening extension. This can also produce more complicated hydrocarbon maturation histories and trap geometries. Multiple phases of rifting and inversion affected numerous basins in North Africa and the Black Sea region and produced some structures that are now prolific hydrocarbon producing fields and others that failed. Understanding a basin's sequence of extensional and contractional events and the resulting complex interactions is essential to formulating successful exploration strategies in these settings.
\end{abstract}

\section{Introduction}

Although the concept of structural inversion has now existed for over a century (Lamplugh, 1919), it was Glennie and Boegner (1981) who explicitly used this term to describe the formation of a specific structure in the southern North Sea. Shortly thereafter Bally (1984) generalized the concept. The importance of inversion tectonics to both academic researchers and industry experts was quickly recognized as shown by several subsequent seminal works (e.g. Cooper and Williams, 1989; Buchanan and Buchanan, 1995). Kley and Krzywiec (2020) provide a discussion of the past 30-year history of positive inversion as a structural geology concept.

Positive structural inversion entails partial or even complete reversal of extensional ("normal") offset on a fault and the formation of associated anticlines. These features are of considerable interest to oil and gas explorationists. The opposite process of negative inversion, in which contractional ("reverse") offset is removed, is generally of less economic significance. "Positive inversion", or just simply "inversion" for the remainder of our discussion, has many effects on all aspects of petroleum systems: maturation, migration, trapping, and sealing. A certain combination of these effects could either improve or degrade the pre-drill risk profile of a hydrocarbon exploration target (e.g. Macgregor, 1995; Turner and Williams, 2004; Cooper and Warren, 2010; Bevan and Moustafa, 2012; Tari et al., 2020). Failure to recognize the impact of inversion on a basin's geologic evolution can have a disastrous impact on an exploration program.

Inversion tectonics become increasingly complex whenever there are multiple phases of extension or shortening, as 


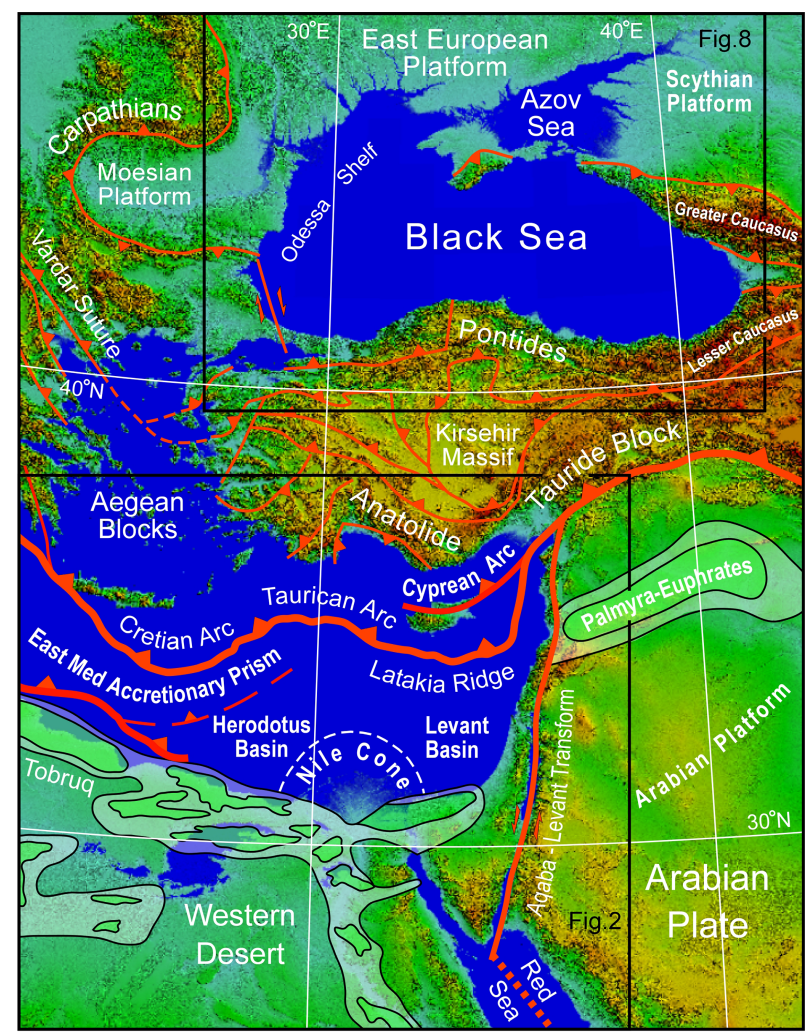

Figure 1. Tectonic setting of the Western Desert (Egypt), eastern Mediterranean and Black Sea. Plate boundaries and major faults are shown in red. Triangles are on upthrown blocks of thrust and reverse faults. Major sedimentary basins of the Western Desert and Arabian plate are shaded in green. Locations of Fig. 2 (eastern part) and Fig. 8 are shown by boxes. Modified from Okay and Tüysüz (1999) and Bosworth et al. (2008) and references therein. Base is SRTM digital elevation model (Jarvis et al., 2008). UTM Zone 36 projection.

compared to the one-time extension-shortening cycle. The general aim of this paper is to provide examples of this complexity by highlighting exploration programs that targeted structures that experienced very different multi-phase inversion histories. We focus on the greater eastern Mediterranean region, where basins present both commonalities and differences in their Neotethyan to present-day tectonostratigraphic histories (Fig. 1). The Western Desert of northern Egypt is selected to show a case in which multiple phases of shortening were separated by multiple syn- and post-rift extensional events. In contrast, the NW Black Sea has a rift basin fabric that was formed by multiple phases of extension during the Triassic to Cretaceous but then was inverted by multiple phases of shortening during the Cenozoic without any intervening extensional periods. Besides illustrating the multifaceted impact on the petroleum system elements, these case studies could also potentially serve as exploration templates in basins with similarly complex tectonostratigraphic evolution.

\section{Western Desert}

The Egyptian Western Desert includes all the land west of the Nile Delta, Nile River, and Lake Nasser to the border with Libya (Fig. 2). The first economic oil or gas discovery in the Western Desert was Alamein field, found by Phillips Petroleum Company in 1966 (Metwalli and El-Hady, 1975; Egyptian General Petroleum Corporation, 1992; 210 million barrels oil (mmbo) in-place resource). The principal reservoir interval is Aptian age dolostone, located in an ENE-WSW-trending elongate faulted anticline. Although not discussed in early interpretations of the field, Alamein is an inverted structure, with shortening imposed in the Late Cretaceous. Other inversion-related traps were subsequently found, including the first oil and gas discovery in the massive Abu Gharadig basin in 1969 (Abu Gharadig field; El Gazzar et al., 2016; 415 million barrels oil equivalent (mmboe) in-place resource). Years later, when the inverted Qarun field was found in 1994, it marked the largest Egyptian discovery in about a decade (Abd El-Aziz et al., 1998; 200 mmboe in-place resource). Unfortunately, many unsuccessful wells were also drilled on the subsurface crests of other large Western Desert inversion folds. Failure was often attributed to the erosion of top seal and breaching of the underlying reservoir objectives.

Alamein, Abu Gharadig, Qarun, and most other Western Desert inverted structures were formed by extension and associated subsidence in the Late Jurassic to Early Cretaceous, followed by shortening in the Late Cretaceous to Eocene. The Late Cretaceous inversion, or "Santonian event", was by far the most significant compressional tectonics to affect the Western Desert during the Phanerozoic, but there were other compressional events. We first briefly outline the tectonostratigraphic history of the Western Desert and then describe less frequently observed inversion in the Early Cretaceous; this is followed by an example of the main Santonian inversion.

\subsection{Geologic setting}

The Phanerozoic history of the Western Desert was shaped by the opening of first Paleotethys and then Neotethys, which morphed into the modern Mediterranean Sea when the seaway between Arabia and Eurasia closed about 15 Ma. Extensional structures related to Paleotethys are present in the subsurface of the Western Desert but are presently not well known. Neotethyan rifting, however, left a complex legacy of multi-phase basins along the northern margin of Gondwana (Fig. 2). Further west in Algeria and Tunisia initial opening began in the Permian and by the Triassic had reached northern Egypt and the Levant and a seaway extended into Syria (Şengör, 1979; Stampfli et al., 2001; Garfunkel, 2004; Berra and Angiolini, 2014). Permian and Triassic continental strata are encountered in wells in the far Western Desert and in outcrops along the Gulf of Suez. Like the Paleozoic section, rel- 


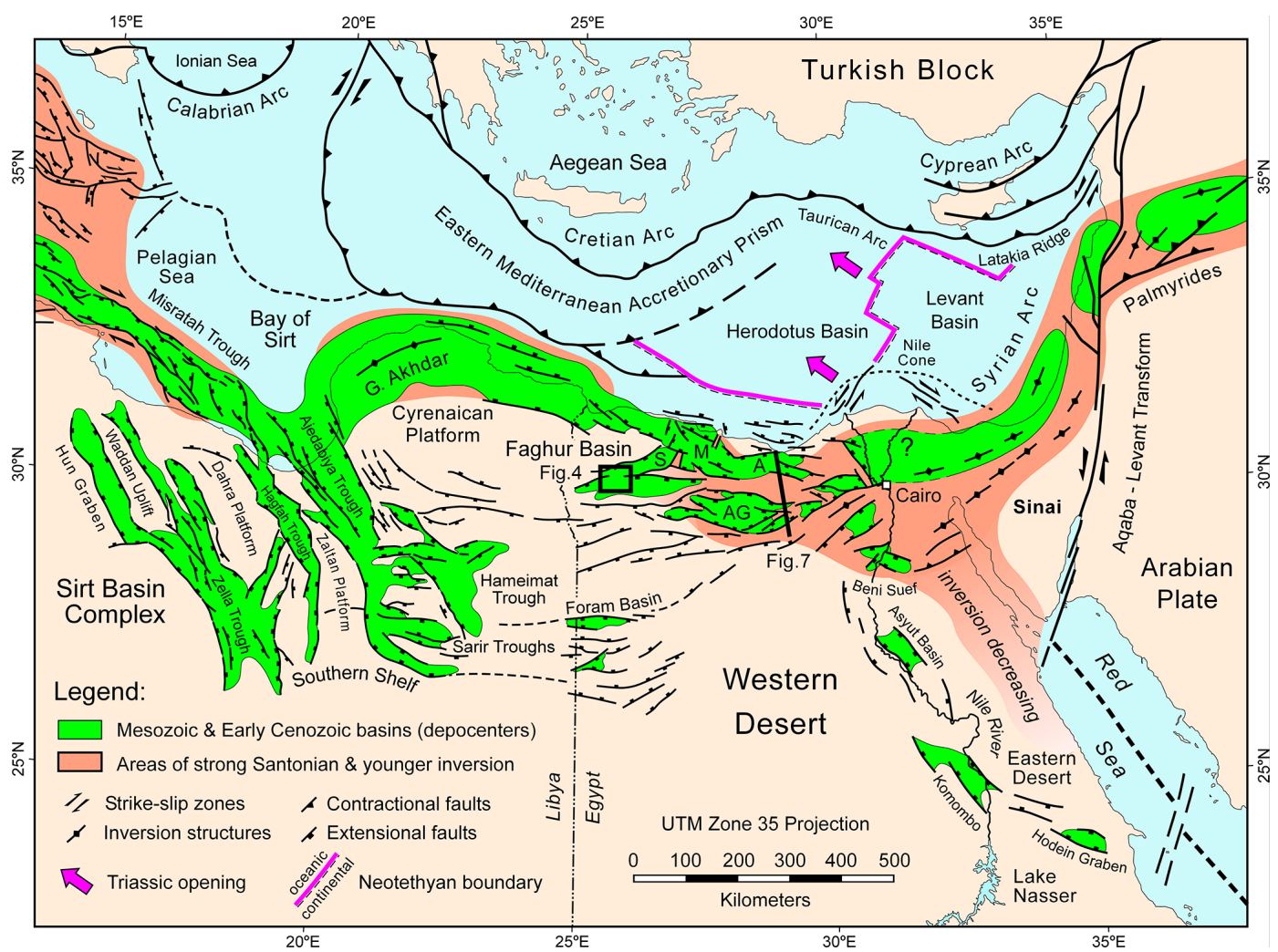

Figure 2. Egypt's Western Desert and its regional geologic setting. Location is shown in Fig. 1. Box shows the location of Fig. 4 and the position of Fig. 7 is indicated. Increasingly milder inversion is observed moving south into the Gulf of Suez region. Similar trends are probably present in the Western Desert, but exposures of suitably aged rocks are generally lacking. A: Alamein basin; AG: Abu Gharadig basin; M: Matruh basin; S: Shushan basin. Triassic opening direction and Neotethyan oceanic-continental crustal boundary after Longacre et al. (2007). Plate boundaries (bold lines), basins, and regions of inversion from Bosworth et al. (2008) and references therein.

atively little is known regarding the structural setting of these units.

The earliest well-defined rifting event in the Western Desert occurred during the Middle to Late Jurassic and established the general basin configuration that persisted through most of the Mesozoic (Keeley and Wallis, 1991; Guiraud, 1998). Most faults active in the Jurassic are oriented E-W to ENE-WSW with an $\sim \mathrm{N}-\mathrm{S}$ extension direction (Fig. 3). This structuration is generally attributed to the distal effects of the continued opening of Neotethys further to the north. However, potential fields and seismic datasets acquired over the past several decades suggest that the eastern Mediterranean basin segment opened with a WNW-ESE extension direction and that the Egyptian margin was a transform boundary (Longacre et al., 2007). Resolving the apparent disconnect between the Egyptian offshore and Western Desert onshore basin kinematics will be important to establishing a better understanding of the geodynamic evolution of NE Gondwana.

In the western Faghur and Shushan sub-basins, Jurassic rifting was marked by an early phase of volcanism, mostly in the form of local basaltic flows, tuffs, and volcaniclastics (Abbas et al., 2019). The volcanics are overlain and interfin- ger with siliciclastic rocks that are ascribed to the Khatatba Formation (Norton, 1967; Fig. 3). The Khatatba Formation is both an important reservoir objective and the most important source rock in the Western Desert (Keeley et al., 1990).

Western Desert "Jurassic" rifting was relatively short-lived and ended in the earliest Cretaceous, spanning a period of $\sim 10 \mathrm{Myr}$ or less $(\sim 150-14 \mathrm{Ma})$. The syn-rift stratigraphy varies dramatically in thickness and facies from sub-basin to sub-basin. In general, the section is much thinner in the west and south and thickens toward the north. At the end of the Jurassic to earliest Cretaceous, a widespread but brief marine incursion resulted in the deposition of Masajid Formation open marine limestone facies over most of the Western Desert, except on a few, high-standing platform areas (Fig. 3; Norton, 1967; Keeley et al., 1990).

Immediately following Masajid flooding, during which active extensional faulting is not recognizable in most subbasins, a second phase of rifting initiated with strata assigned to the Alam el Bueib Member of the Burg el Arab Formation (Fig. 3; Norton, 1967). This is the most pronounced extensional phase in most Western Desert sub-basins and lasted about $14 \mathrm{Myr}(\sim 139-125 \mathrm{Ma})$. Extension was also initially 


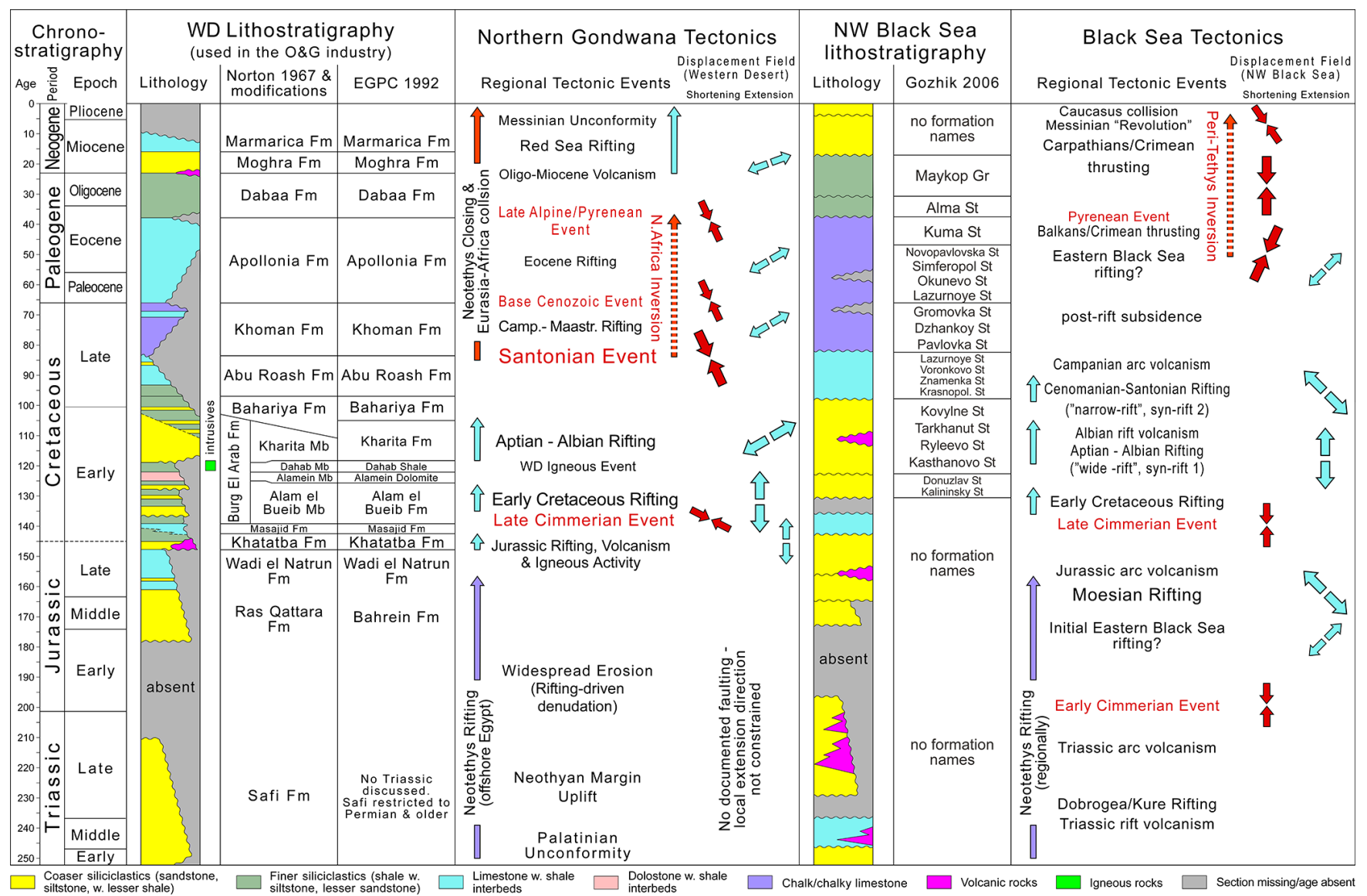

Figure 3. Mesozoic to Cenozoic tectonostratigraphy of the Western Desert and Black Sea regions. Extensional and shortening events are separated for clarity. In some basins both extensional and contractional inversion structures are observed to have developed simultaneously. Timescale is from Ogg et al. (2016). Gr: group; Fm: formation; Mb: member; St: suite.

$\mathrm{N}-\mathrm{S}$ directed, but midway through the rift event, extension rotated to NE-SW (Fig. 3).

In addition to the strong clockwise rotation of the extensional stress field, which is also recognized in many other basins of north and central Gondwana (Guiraud and Bellion, 1995; Guiraud, 1998; Guiraud and Bosworth, 1999; Guiraud et al., 2001, 2005), the Western Desert experienced a pulse of compression at about $138 \mathrm{Ma}$, which we refer to as the late Cimmerian event (Fig. 3). This shortening only affected a small number of faults, an example of which is discussed below.

The Alam el Bueib phase of rifting, like the Khatatba, ended with a second even more regionally extensive marine flooding event, which deposited the Alamein and Dahab members (Norton, 1967). NE-SW-oriented extension renewed in the mid-Aptian at about $120 \mathrm{Ma}$, and marine deposition was replaced by predominantly fluvial deposits of the Kharita Member and Bahariya Formation (Said, 1962; Norton, 1967). Kharita-Bahariya rifting was prolonged, lasting about $20 \mathrm{Myr}(\sim 120-100 \mathrm{Ma})$, but generally occurred at slower extension rates that gradually dissipated in lower Ba- hariya times. In other parts of Gondwana, the Albian-Aptian was the most important phase of extension, as was the case in much of the central African rift system (Schull, 1988; McHargue et al., 1992; Bosworth, 1992).

Sea-level rise in the Cenomanian and Turonian resulted in flooding of all the Western Desert and establishment of an epeiric sea that would last into the early Cenozoic (Said, 1962; Kerdany and Cherif, 1990). These marine strata are assigned to the upper Bahariya and Abu Roash formations (Fig. 3; Norton, 1967) and were deposited during a relatively quiescent period in the Western Desert. In the Sirt basin to the west (Fig. 2), this was a time of significant extension and subsidence in its NW-SE-trending sub-basins (Wennekers et al., 1996; Abadi et al., 2008). The Western Desert calm was abruptly terminated at $84 \mathrm{Ma}$ with the onset of the main pulse of regional basin inversion, the Santonian event (Moustafa and Khalil, 1995; Guiraud and Bosworth, 1997; Guiraud, 1998; Bevan and Moustafa, 2012). Santonian compression, shortening, and inversion were of true platescale significance, as was recognized long ago by Burke and Dewey (1974). 
Santonian inversion can be interpreted to be a consequence of a change in relative movement between the Eurasian and African plates, with $\mathrm{N}-\mathrm{S}$ divergence switching to N-S slightly oblique convergence (Savostin et al., 1986; Le Pichon et al., 1988; Dewey et al., 1989). Convergence continues to the present day and was manifest in North Africa by a series of compressional pulses, interspersed with periods of quiescence or extension that were spatially complex (Bevan and Moustafa, 2012). The most pronounced post-Santonian shortening occurred at the end-Cretaceous and within the late Eocene, corresponding to coeval compressional maxima in the Alpine belt of Eurasia (Fig. 3; Guiraud et al., 1987; Guiraud and Bosworth, 1997; Guiraud, 1998).

During and following Santonian inversion, shallow marine carbonate environments continued across the Western Desert with deposition of the Khoman Formation (Fig. 3; Norton, 1967). The Khoman, which is commonly a chalky facies, is completely missing from the crests of some major Santonian inversion structures. Apollonia Formation (a term borrowed from Libyan stratigraphy) limestone deposition commenced following the base Cenozoic unconformity and generally continued until the late Eocene deformation when the northern Western Desert epeiric seas began to retreat and siliciclastic deposition returned (Dabaa Fm.; Norton, 1967). Mixed carbonate and siliciclastic deposition continued through the Oligocene and Miocene (Moghra and Marmarica Fms.; Said, 1962), punctuated by a very brief period of basaltic volcanism at 24-22 Ma that was related to Red Sea rift initiation (Fig. 3; Meneisy, 1990; Bosworth et al., 2015a). Most of the Western Desert, excluding some coastal regions, experienced gradual uplift and erosion from the late Miocene to the present day.

\subsection{Faghur basin Cimmerian inversion}

Faghur is the westernmost sub-basin of the northern Egyptian Western Desert rift system (Fig. 2). Exploration started there in the late 1950s encouraged by success to the west in the basins of Libya. However, the first commercial discovery was not made until 2006. The only documented functioning source rock in the Faghur basin is the Khatatba Formation (Bosworth et al., 2015b; Fig. 3), which was deposited during the short-lived Late Jurassic first phase of rifting. The Alam el Bueib-6 unit at the base of the second more profound Early Cretaceous rifting event may also have local source potential at Faghur.

Extensional faults that affect the Khatatba and immediately overlying Masajid Formation strike predominantly in two orientations: E-W or ENE-WSW (Fig. 4). Like the other main sub-basins of the Western Desert, most of these faults dip to the south, which is significant as the coeval Neotethyan margin stepped down to the north. The south dip probably reflects reactivation of a pre-existing basement or Paleozoic (Hercynian?) structural fabric.

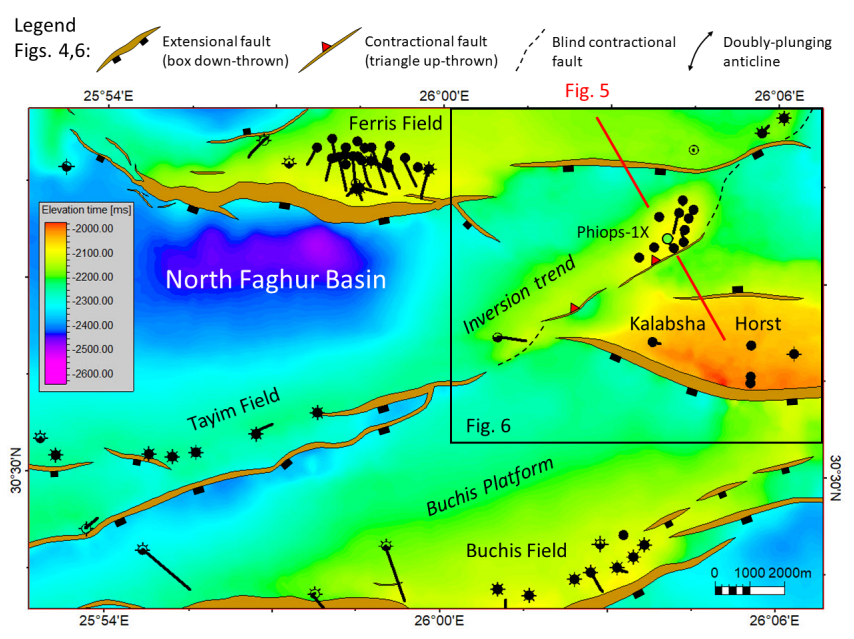

Figure 4. Inverted structure trend of the Phiops field shown on a time structure map of the eastern North Faghur basin. Mapped horizon is top Khatatba Formation. Location of the map is shown in Fig. 2. Position of Fig. 5 is indicated. The reverse fault that inverts the structure becomes a blind fault along-strike but can be observed at deeper horizons.

The only places where an early phase of shortening and inversion have been observed are on a few of the ENE-WSWstriking faults, as along the Tayim-/Phiops trend (Fig. 4). There the inversion affected a small segment of the fault system that dipped NW, just north of the large Kalabsha horst block. Early syn-rift growth on this fault was small but resolvable (Fig. 5). Inversion occurred during deposition of the basal units of the Alam el Bueib Member, so in very early Cretaceous times. Based on this timing and in accordance with the better documented tectonic phases of SE Europe we designate the inversion a "late Cimmerian" event (Nikishin et al., 2001; Stampfli et al., 2001). Minor folding and local erosion of this age have been observed elsewhere in North Africa, the Benue trough, the Levant margin, and the Arabian platform (summarized in Guiraud et al., 2005).

Alam el Bueib syn-rift phase 2 strata drape over and seal the inversion anticline (Fig. 5). Differential compaction across the structure affected most of the mid- and upper Alam el Bueib strata resulting in four-way dipping (domal) unfaulted closures higher in the section. In detail, the hinge of the Phiops fold is doubly plunging and not exactly parallel to the underlying contractional fault (Fig. 6). The hinge curves away from the ENE-WSW-striking fault becoming NE-SW trending. This suggests that the shortening direction was approximately NW-SE oriented. Along strike several other smaller inversion anticlines are recognized, and to the north the fold trend steps to the east across another major down-to-the south early extensional fault.

In the Faghur basin oil migration commenced in the Late Cretaceous (Bosworth et al., 2015b; Abdelbaset et al., 2019), long after the late Cimmerian inversion structure was formed. 


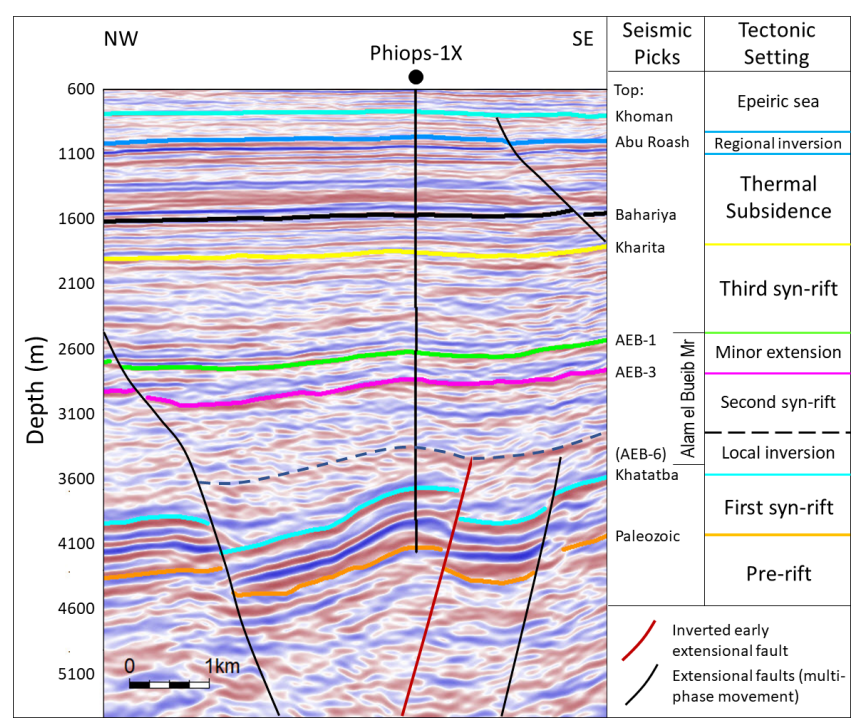

Figure 5. Depth-migrated seismic line through the inversion structure at Phiops field. Inversion occurred during the deposition of the lower part of the Alam el Bueib Member. This was followed by differential compaction over the structure but no further shortening. The later Santonian "regional inversion" did not significantly impact this part of the Western Desert, but its effects are locally observable. Location is shown in Fig. 4. For ages of seismic markers, see Fig. 3. 1.7 vertical exaggeration.

Reserves are trapped in both pre- and post-inversion siliciclastic reservoirs. The amount of shortening at Phiops is not large, although it did remove all the early extension on the fault and all units now display reverse offset. The Phiops inversion is restricted to a single fault trend and had no noticeable effect at the scale of the Faghur sub-basin. No reserves have so far been recovered from the overthrust footwall block.

The products of younger inversion are present in the Faghur basin but are very minor. Structures formed by Santonian shortening include small folds of the Abu Roash strata (Fig. 3) along the large basin-bounding faults. This was of no consequence to the hydrocarbon system of the sub-basin. Slightly more significant was renewed NE-SW-directed extension and accompanying sedimentation during the Campanian and Maastrichtian, which provided additional overburden and therefore helped to accelerate maturation of the deep Khatatba source rocks. Late Cretaceous NW-SE shortening and NE-SW extension were probably at least in part coeval at Faghur.

\subsection{Alamein-East Abu Gharadig basins Santonian inversion}

Late Cretaceous shortening in the Western Desert has been extensively documented, both in outcrop (Moustafa, 1988; Abdel Khalek et al., 1989; Moustafa et al., 2003) and the subsurface (Kerdany and Cherif, 1990; Moustafa et al., 1998;

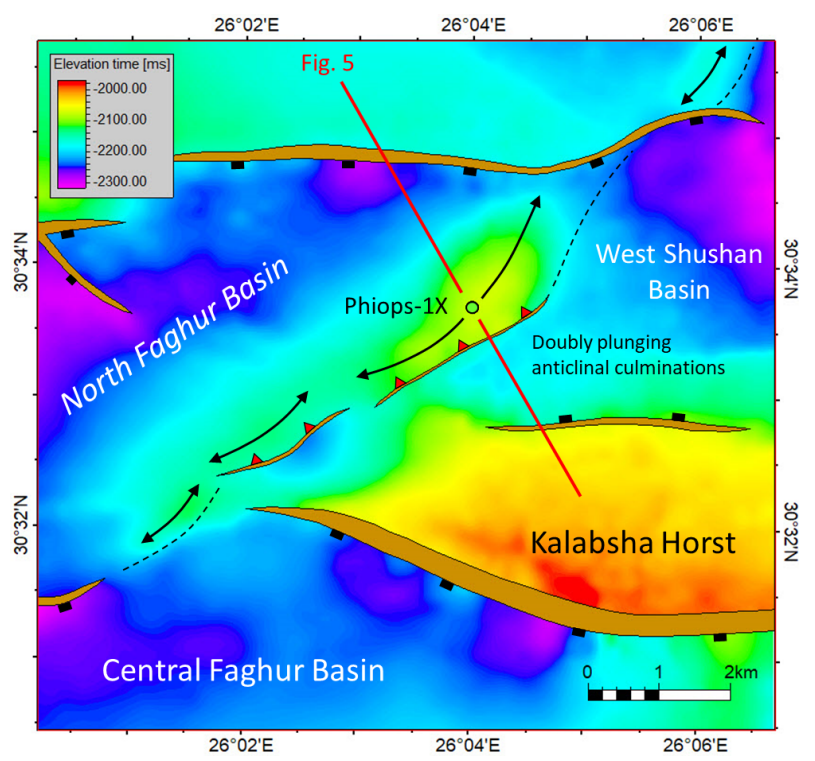

Figure 6. Detailed top Khatatba Fm time structure map of the Phiops inversion trend. Other wells have been removed for clarity. See Fig. 4 for location and legend. Position of Fig. 5 is indicated.

Yousef et al., 2010, 2019; Bevan and Moustafa, 2012). In the eastern sub-basins of the Western Desert, inversion is manifest at both the scale of individual faults and across complete sub-basin profiles. Shortening was intense in the Alamein, Abu Gharadig, and Matruh sub-basins (Fig. 2) but as discussed above largely absent from the westernmost regions. Near the border with Libya, almost all the Late Cretaceous shortening occurred further to the north in Cyrenaica, which acted as a promontory or indenter during the EurasiaGondwana collision (Bosworth et al., 2008).

A regional transect of the Alamein and East Abu Gharadig basins illustrates the scale and significance of Late Cretaceous and younger inversion in the eastern Western Desert (Fig. 7; see also Bevan and Moustafa, 2012, their Fig. 19.7). The stratigraphy of the eastern sub-basins is very similar to that of Faghur in its overall framework. In detail, several differences can be noted: (1) the pre-Jurassic stratigraphic section is much thinner or absent completely; (2) particularly in the north, depositional facies in the Jurassic and Cretaceous tend to display more marine affinities; (3) thickness variations in the Cenozoic section are much more dramatic, in part due to the effects of late inversion; and (4) a gentle, regional northward tilt of the late Miocene to Holocene section, particularly in the Alamein basin (not observed in Faghur).

The most pronounced shortening at the longitude of Fig. 7 occurred at the Mubarak inversion where crystalline basement now structurally overlies part of the early syn-rift stratigraphy. The inverted fault at this position was not the original basin-bounding fault but rather cuts through the axis of the early basin. The area is covered by goodquality 3D seismic reflection data, and along-strike the basin- 


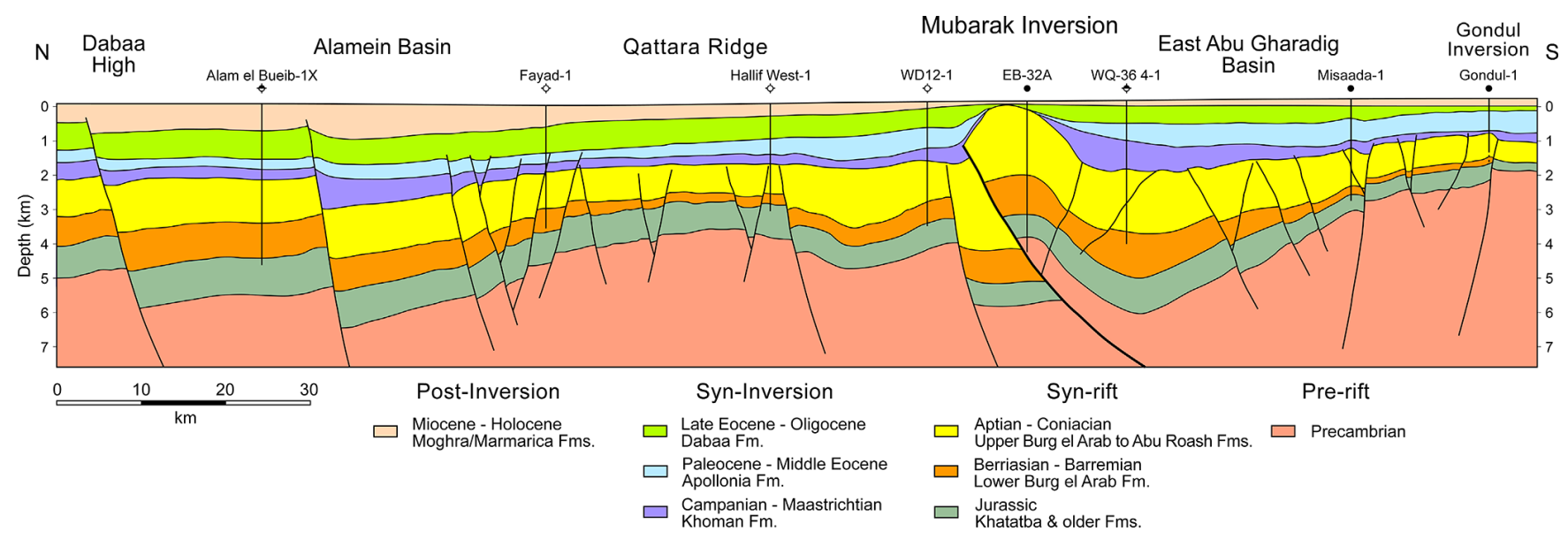

Figure 7. Regional geoseismic section across the eastern part of the Western Desert. Location is shown in Fig. 2. The massive Mubarak inversion is one of the best examples of Western Desert Santonian inversion followed by younger pulses of shortening. After Bosworth et al. (2008). Four times vertical exaggeration.

bounding and inverted faults merge to produce a more "typical" inverted extensional fault. Other less prominent inversion structures, more akin to the scale of Early Cretaceous Cimmerian shortening described at Faghur, are present at Misaada and Gondul (Fig. 7).

The most prominent inversion-related unconformity across all these eastern basin structures initiated in the Santonian. Pronounced onlap of the Campanian-Maastrichtian Khoman chalk onto the Mubarak fold is evident in seismic lines (Bevan and Moustafa, 2012). A second, dramatic unconformity at Mubarak developed at the end of the Mesozoic, indicating renewed shortening and denudation that continued into the late Eocene.

The total Jurassic to present-day stratigraphic thickness of the Alamein, East Abu Gharadig, and Faghur basins are quite comparable, generally $5-6 \mathrm{~km}$ in the vicinity of the main basin axes. However, the geothermal gradients at Alamein and East Abu Gharadig are higher than at Faghur, and therefore oil generation commenced earlier, generally in the midCretaceous. Migration was well underway by the time of the Santonian inversion and more so for the later pulses of compression. Breaching of some reservoirs that had already trapped hydrocarbons was inevitable. Fortunately for the inversion structures in Fig. 7, numerous reservoir horizons remained intact and Early Cretaceous syn-rift exploration targets were successful.

\subsection{Significance of multiple inversion events to Western Desert hydrocarbon systems}

The exploratory wells drilled on the inversion structures of Figs. 5 and 7 were all successful. Along strike, other wells were not so lucky. Other parts of the Mubarak inversion were uplifted and eroded more deeply than at the EB-32A location. In some cases, wells encountered reservoirs with residual hydrocarbons suggesting that oil migration and trapping occurred and then was lost. The Phiops, Misaada, and Gondul trends are much smaller structures than Mubarak, and all display very complex local fault patterns. Offset locations and similar play types to these wells were not always successful either.

In addition to breaching structurally shallow reservoirs, the large Western Desert inversions such as Mubarak also interrupt hydrocarbon maturation processes, at least over the region undergoing significant uplift. Estimating how much stratigraphic section was removed, rather than nondeposited, is a complex and difficult problem to address as relevant data (e.g., thermochronometric) are often lacking. The potential effects of inversion-driven denudation on paleo-heat flow are another consideration, generally not wellconstrained or even considered.

Basin-scale inversions like Mubarak also drastically impacted migration pathways (Bevan and Moustafa, 2012). Prior to Santonian inversion, almost all hydrocarbons being generated and expelled from the Jurassic Khatatba Formation in the East Abu Gharadig basin were flowing through carrier beds up-dip to the south, toward Misaada and Gondul (Fig. 7). During Santonian and younger inversion, the basin axis progressively migrated to the south, with more and more of the deeper stratigraphic section rotating and ultimately dipping to the south, refocusing migration to the north. Understanding these changes in migration paths, which can occur at both local and regional scales, is important to successful exploration strategies.

\section{Black Sea}

The Black Sea is classically divided into two separate basins - the western and eastern Black Sea basins (WBSB and EBSB) - with the divide formed by the Andrusov and 


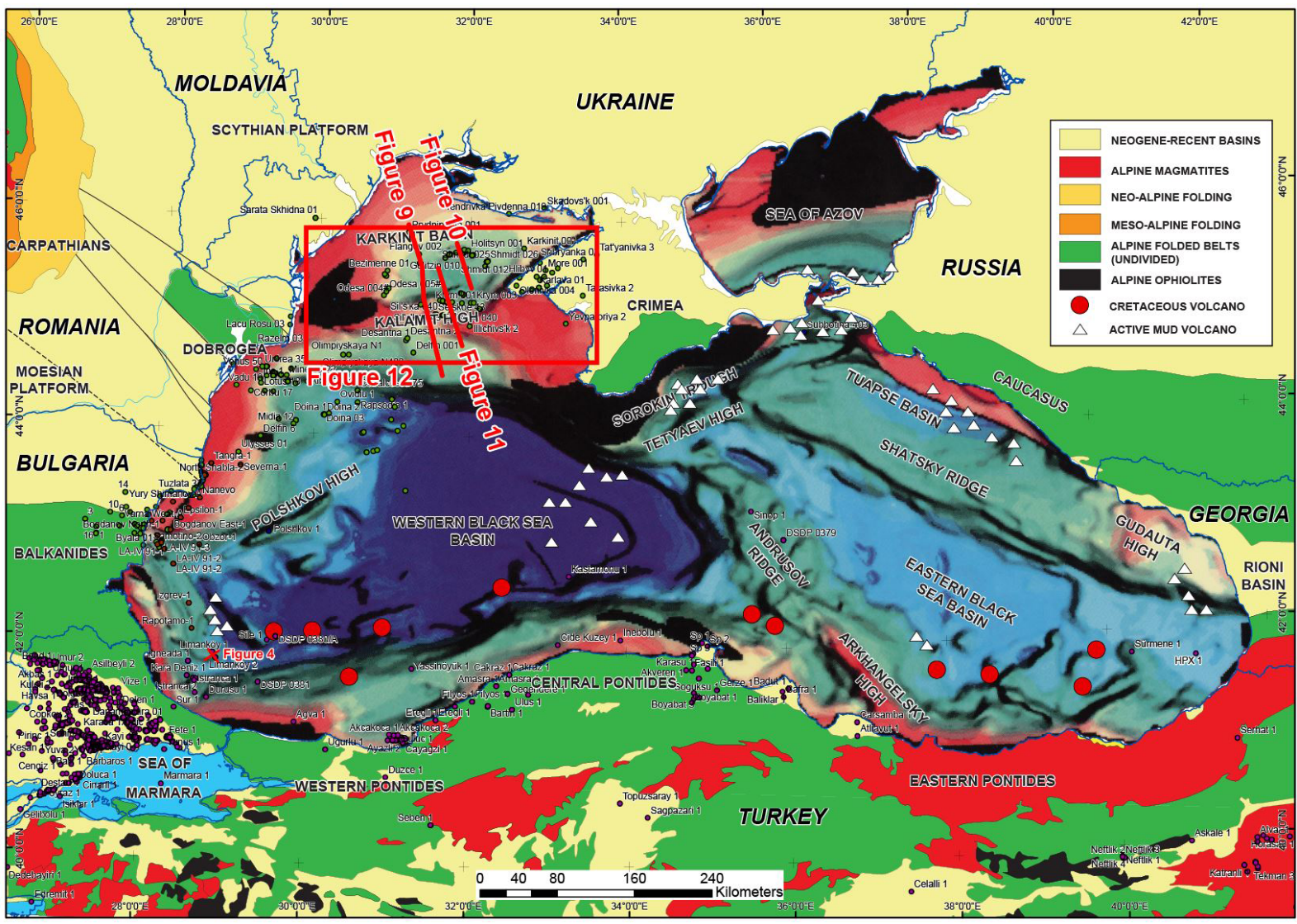

Figure 8. Simplified structural map of the Black Sea modified from Tari and Simmons (2018). Location is shown in Fig. 1. Within the Black Sea itself, the depth-to-break-up unconformity is shown, cold colors indicating greater depth, adapted from Robinson (1997). Black lines between the Carpathians and the Black Sea correspond to major faults pre-dating the opening of the Black Sea (Krezsek et al., 2017). White triangles represent offshore mud volcanoes and red dots represent Cretaceous paleo-volcanoes (Nikishin et al., 2015a). The locations of a depth-converted, regional seismic line (Fig. 10), two vintage seismic profiles (Figs. 11 and 12), and a Maykop (Oligocene to lower Miocene) isopach map (Fig. 13) are shown by red lines.

Arkhangelsky ridges and the Tetyaev high (collectively, the mid-Black Sea high), which trend approximately northsouth in the central part of the Black Sea (Fig. 8). Our study area is in the broader Gulf of Odessa (or Odessa Shelf) located in the northern part of the WBSB. Our database is composed of about $8000 \mathrm{~km}$ of legacy $2 \mathrm{D}$ reflection seismic data and close to 90 wells drilled for hydrocarbon exploration purposes.

There are several examples of inversion structures with associated hydrocarbon fields in the Black Sea. In the Histria trough of Romania (Fig. 8), multiple phases of Cenozoic inversion have been described (Morosanu, 2002; Dinu et al., 2005). Drilling in the Romanian Black Sea started in 1976 and led to the discovery of the Lebada field in 1981, which has a trap with an element of inversion (Krezsek et al., 2017). In the Turkish sector, the biogenic gas field of Akcakoca was discovered by Turkish Petroleum in 1976 (Fig. 8). Subsequent drilling proved the commerciality of this gas find reservoired in middle Eocene turbidites. The trap for this field is an inverted anticline (Robinson et al., 1996; Alaygut et al., 2004; Menlikli et al., 2009) due to the regional shortening associated with late Eocene basin-scale inversion. In the Gulf of Odessa of Ukraine the first offshore discovery was Golitsyna in 1975 (Fig. 8), an anticline with Paleocene chalk and Oligocene sandstone reservoirs displaying renewed episodes of inversion after the largest late Eocene one (Robinson and Kerusov, 1997; Khriachtchevskaia et al., 2009, 2010).

After briefly describing the tectonostratigraphic evolution of the WBSB, we provide a modern, depth-converted, regional-scale seismic illustration of the multiple inversion periods in the Karkinit basin, Shtoromoe graben, and Kalamit high area (Fig. 8). An additional legacy 2D seismic example was selected to show the untested deep gas potential along the northern perimeter of the inverted Karkinit basin. Finally, we highlight the un(der)explored intra-Maykop stratigraphic play potential. This is directly linked to the strongest late Eocene inversion episode in the Black Sea area, which created pronounced lateral variations in accommodation space. 


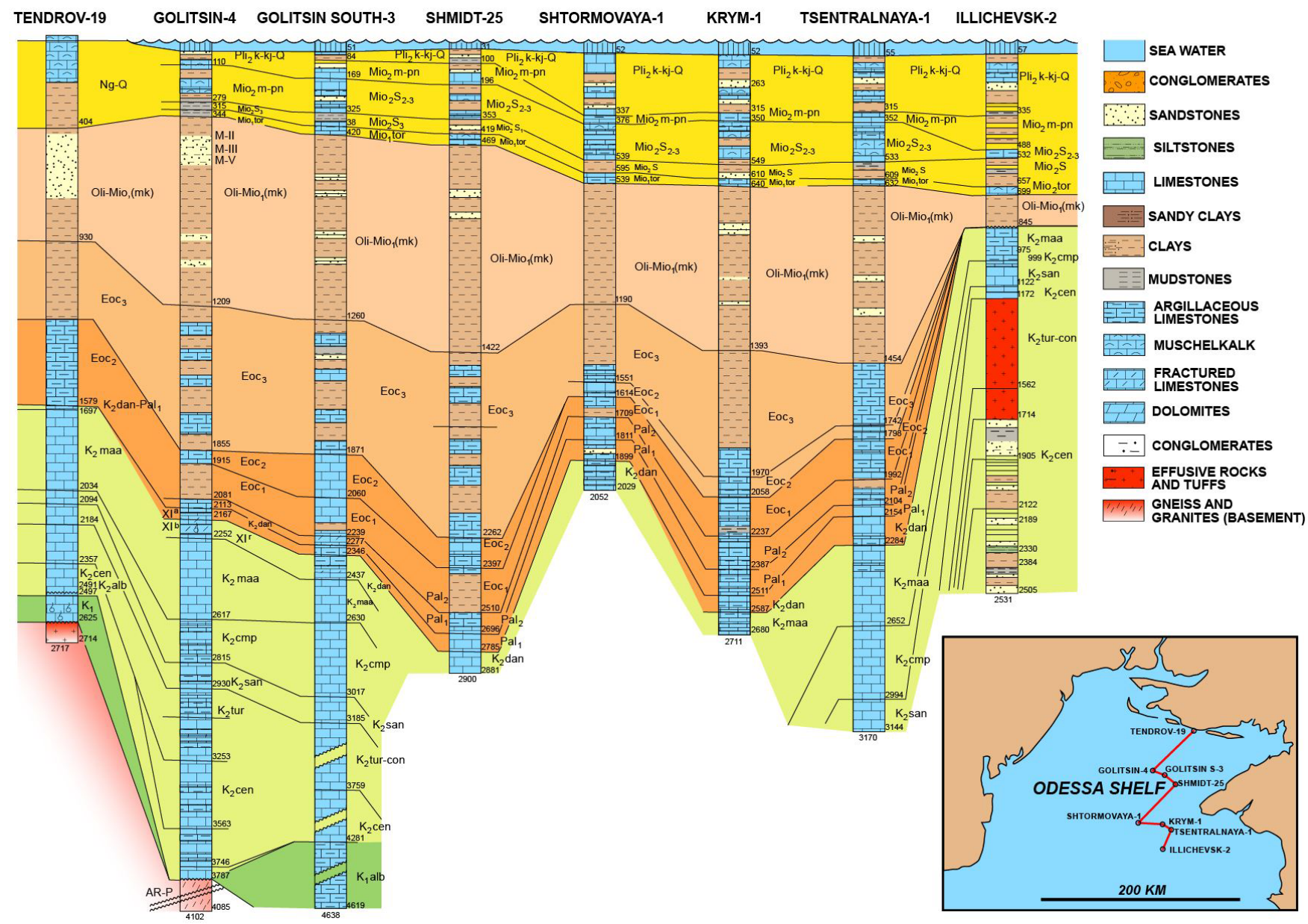

Figure 9. Regional correlation of wells drilled on the Odessa Shelf, compiled from various sources (e.g. Gozhik et al., 2006, 2010). For location, see map inset. Depth of stratigraphic tops are in meters. Note that none of the deep basins (e.g. Karkinit basin) have been penetrated to their full depth, unlike the basement highs (e.g. Kalamit high).

\subsection{Geologic setting}

The Black Sea is a Cretaceous basin complex superposed on the northern margin of the Tethys/southern margin of Laurussia (Nikishin et al., 2001; Okay and Nikishin, 2015). The Mesozoic pre-rift tectonostratigraphy of the WBSB is quite complex as it has elements of Early to Middle Triassic rifting, Late Triassic-Early Cimmerian orogenesis, Jurassic back-arc extension, and the Late Jurassic-late Cimmerian regional compressional phase (Fig. 3; Nikishin et al., 2001). These alternating extensional and compressional cycles produced inverted structures, like those of the Triassic rifts on the Scythian Platform and in Dobrogea (Saintot et al., 2006), but these are typically poorly understood subsurface features.

The Black Sea basin complex is traditionally thought to be a marginal or back-arc basin with active rifting beginning in the mid-Cretaceous (Finetti et al., 1988; Nikishin et al., 2015a, b). In terms of geodynamic models of modern backarc basin formation, this extension was driven by slab roll- back (Stephenson and Schellart, 2010). However, a debate in the literature is still ongoing regarding not only the geodynamic reason for the basin opening but also its timing and kinematics (Tari, 2015; Tari et al., 2015).

The Black Sea basin opened in a complex manner and Tari (2015) distinguished two major rifting periods within the Cretaceous. Initial rifting started as soon as the Barremian and became regionally widespread in a "wide-rift" mode by the Aptian-Albian (syn-rift stage 1; Fig. 3) with numerous rift sub-basins trending NW-SE or E-W (Robinson and Kerusov, 1997; Krezsek et al., 2017). There is surface and subsurface evidence for Albian volcanics in the area, including western Crimea (Nikishin et al., 2013), and the mostly andesitic volcanism appears to be limited to the EW-trending Karkinit basin. The trend of rifting changed to NE-SW at the end of the Albian and a new rifting period occurred during the Cenomanian to Santonian (syn-rift stage 2; Fig. 3). During this time a "narrow-rift" style of much largerscale regional volcanic back-arc extension was superimposed 


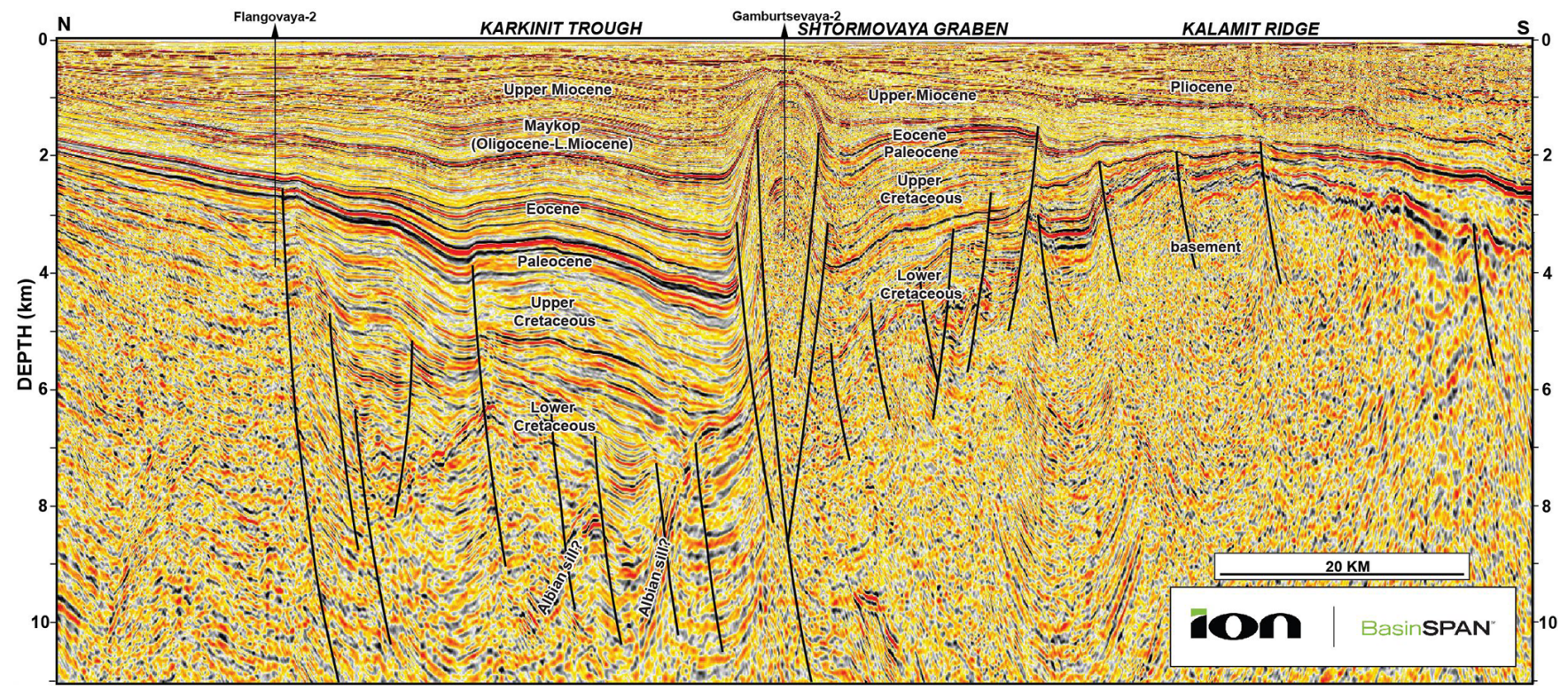

Figure 10. Regional-scale pre-stack depth migrated (PSDM) seismic reflection profile across the Odessa Shelf, courtesy of ION. For location, see Fig. 8. Note the $>7500 \mathrm{~m}$ deep Karkinit trough in the middle of the section and the Kalamit ridge to the south of it. Approximately five times vertical exaggeration.

on the Early Cretaceous, mostly a non-volcanic extensional system. By the Santonian, the WBSB opened to its full extent and in our study area the top Santonian is considered by Khriachtchevskaia et al. (2010) as the ultimate break-up unconformity.

Since the first basin-wide distributed volcanics are Turonian in age, the WBSB evolved as a sensu stricto backarc basin only during the Turonian-Santonian interval (Tari, 2015). The subsequent widespread Campanian volcanism in the Pontides, and its assumed equivalent in the Turkish offshore area (Nikishin et al., 2015a), was interpreted by Tari (2015) as being arc-related but post-dating the opening of the WBSB.

The uppermost Cretaceous and lower Paleogene (Paleocene to middle Eocene) stratigraphy of the Odessa Shelf is dominated by chalks (Figs. 3, 9), reflecting tectonic quiescence in a post-rift setting. The first compressional event disrupting the waning subsidence pattern happened at the end of the middle Eocene at about $38.6 \mathrm{Ma}$ (Khriachtchevskaia et al., 2010), and the deposition of carbonates was replaced by shales (Figs. 3, 9). During the late Eocene at about 35.4 Ma, another basin-wide shortening episode produced the bulk of the inverted structures (Khriachtchevskaia et al., 2010). This "Pyrenean" event (Fig. 2) is considered as the most significant one in the broader Black Sea area, and it can be correlated with the last phase of overthrusting in the Balkans (Doglioni et al., 1996; Bergerat et al., 2010). The Crimean Mountains also experienced shortening-related uplift during this time based on apatite fission-track studies (Panek et al., 2009).
Regionally, the Oligocene to lower Miocene Maykop Formation (Vernyhorova and Ryabokon, 2020; Figs. 3, 9) postdates the two Eocene discrete inversion events as can be deduced from the onlap geometries seen on reflection seismic data (Fig. 10). The early and middle Miocene saw another two inversion events (circa 16.3 and 10.4 Ma) in our study area (Khriachtchevskaia et al., 2010). The pronounced diapir-looking structure (Gamburtsev) in the middle of the regional seismic line (Fig. 10) is an extreme example of the multiple contractional reactivation of an already existing inverted structure. The inversion process was quite selective spatially and temporarily across the Odessa Shelf, as not all the pre-existing Cretaceous master faults were reactivated in any given cross section (Fig. 10). However, the large border fault on the northern margin of the Karkinit basin did experience reactivation along strike to the east in the area of the Golytsina gas-condensate field (Fig. 11). The seismic expression of both the footwall and hanging wall is clear and even the position of the null point can be determined with confidence. The inversion clearly post-dated the Maykop Formation and therefore is post-early Miocene in age.

The Sudak folded belt offshore Crimea (Tari and Simmons, 2018) formed during the Miocene (Stovba et al., 2009, 2013, 2017; Sheremet et al., 2016a, b) in multiple stages (Fig. 3). The corresponding Miocene compressional episodes with slightly rotating but generally $\mathrm{N}-\mathrm{S}$-oriented compressional stress fields were documented by micro-tectonic studies in onshore Crimea (Murovskaya et al., 2014; Hippolyte et al., 2018). The challenge onshore, just like in the offshore, is that these stages or events cannot be precisely dated, i.e. 


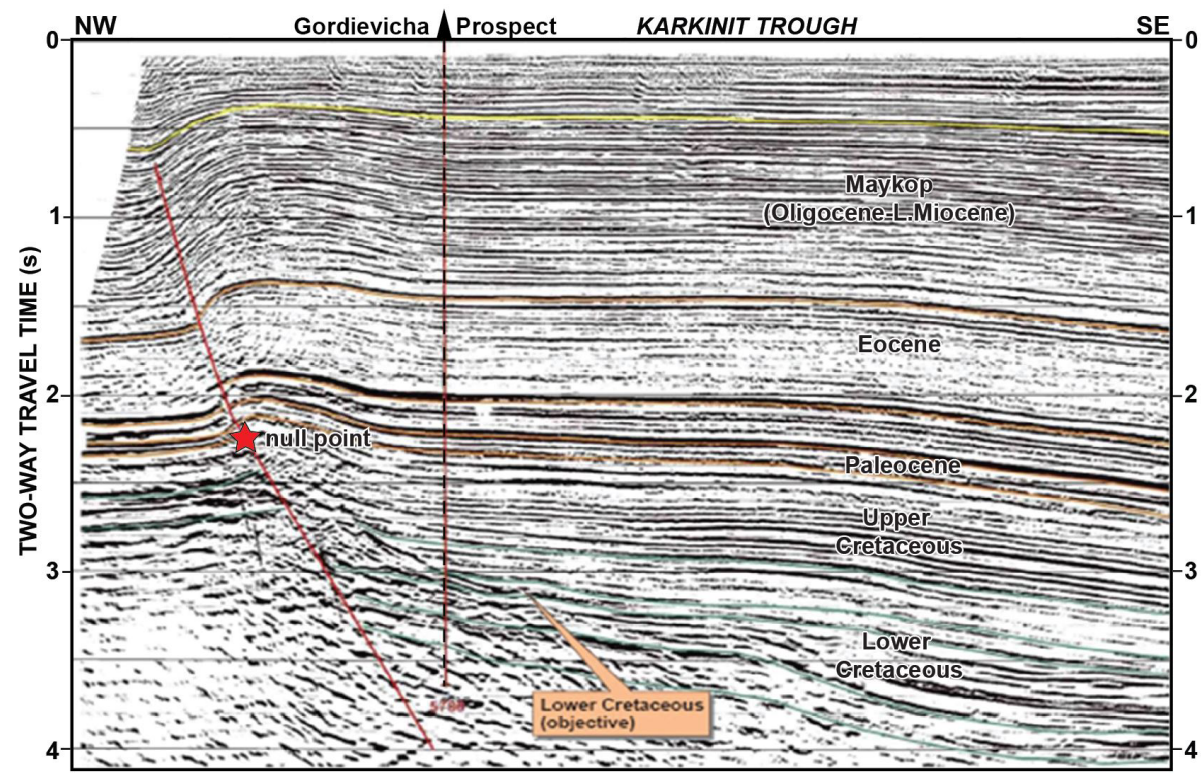

Figure 11. Legacy 2D seismic reflection profile across the undrilled Gordievicha prospect, adapted from Burchell (2008). For location, see Fig. 8. The position of the null point, sensu Williams et al. (1989), is shown by a red star.

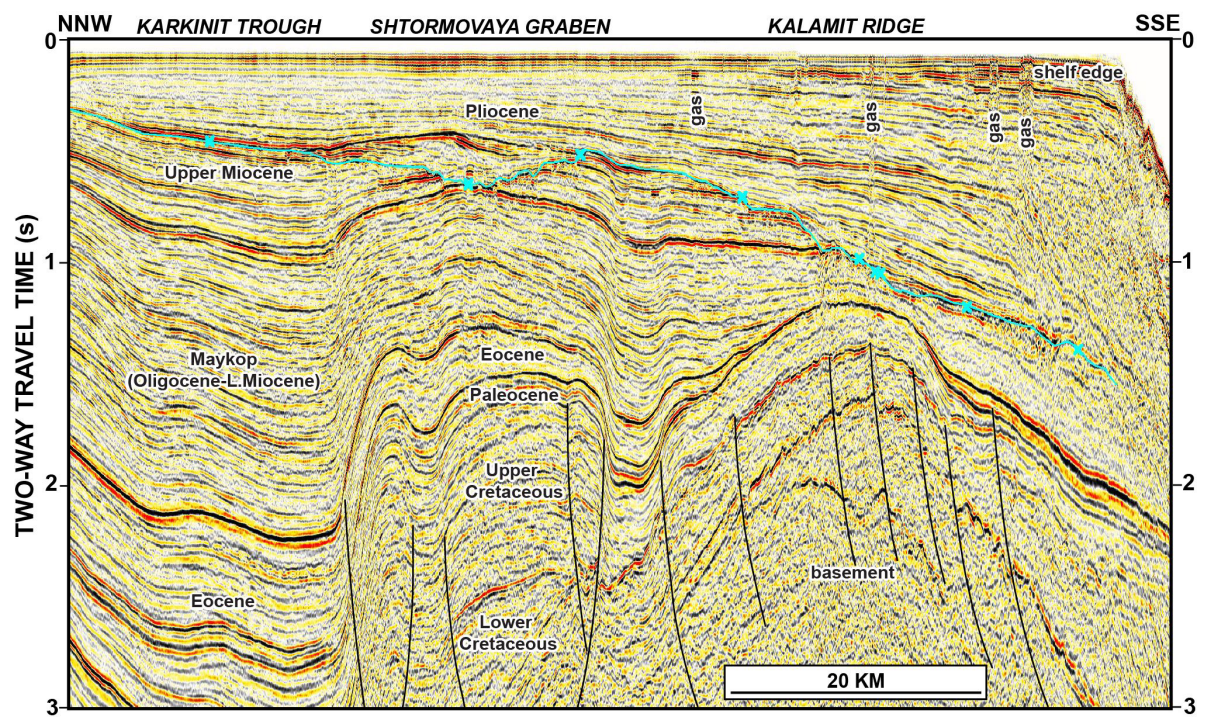

Figure 12. Seismic reflection evidence for post-Sarmatian inversion. For location, see Fig. 8. The southward prograding Pliocene sequence above the Sarmatian (late Miocene) unconformity (shown in blue) is clearly back-rotated. This is due to the multiple episodes of inversion forming the overall structure containing the relatively small Shtormovaya field on its northern flank (e.g. Khriachtchevskaia et al., 2009). Note the gradual incorporation of the earlier Eocene folds into a much larger Miocene to Pliocene inversion anticline. Vertical exaggeration is $\sim 6 \times$ assuming an average seismic velocity of $4 \mathrm{~km} \mathrm{~s}^{-1}$.

with a resolution of less than $1-2 \mathrm{Myr}$, and separated thus far. This limitation is primarily due to the lack of Miocene sediments in the Crimean Mountains onshore and the lack of sufficiently dense sampling of the stratigraphy in offshore industry wells.

Khriachtchevskaia et al. (2010) argued that the period of discrete inversion ended by the late Miocene or at least was suspended. This is contrary to the models of Robinson et al. (1995) and Nikishin et al. (2003), who suggested an accelerated period of subsidence in the Black Sea basin complex since the late Miocene or Pliocene, respectively, as the result of an overall $\mathrm{N}-\mathrm{S}$-directed compressional stress regime down-bending the basin center. Whereas this subsidence is difficult to document given the resolution of the biostrati- 
graphic dating, a closer look at the available seismic reflection data does provide definitive evidence for ongoing postlate Miocene compression in the Gulf of Odessa.

We chose a legacy 2D seismic line across the Shtormovoe inversion anticline to show how this particular feature displays signs of repeated and also neotectonic shortening (Fig. 12). This broad, $20 \mathrm{~km}$ wide structure is a composite one at depth; below about $1 \mathrm{~s}$ two-way travel time, it splits into two inversion anticlines, 4 and $12 \mathrm{~km}$ across. These correspond to earlier Eocene inversion events. With the continuous thickening of the sedimentary cover, the earlier Eocene inversion anticlines were incorporated into a broader, single Miocene to Pliocene anticline.

A key observation regards the geometry of a prograding shelf margin sequence over the apex of the structure which postdates the pronounced regional intra-Sarmatian (Khersonian) unconformity dated as circa $7.5 \mathrm{Ma}$ in the Black Sea (Fig. 12; Popov et al., 2010). The clinoforms in this prograding unit are slightly back-rotated to the north and their top laps, which should be sub-horizontal, show $\sim 2-4^{\circ}$ northward tilt (Fig. 12). There are also two onlapping reflectors on the northern flank above the prograding sequence. Given the dimensions of the structure and the timing, this back-rotation cannot be attributed to differential compaction. These observations underscore the reactivation of the inversion process during the Pliocene.

The present-day stress field in the area, based on earthquake focal mechanism studies, is a compressional-to-strikeslip one (Murovskaya et al., 2018) which is consistent with other regional observations of ongoing $\mathrm{N}-\mathrm{S}$-directed compression in the broader Black Sea area (Tsereteli et al., 2016).

\subsection{Implications for NW Black Sea exploration}

There are several hydrocarbon fields in the Gulf of Odessa and the adjacent Crimean Peninsula (Fig. 13). The Odessa Shelf was explored for the last 5 decades, and eight gas and gas-condensate fields have been discovered, all drilled in jack-up water depth (less than $100 \mathrm{~m}$ ). Exploration was historically focused on the inverted structural highs. The productive horizons are related to Upper Cretaceous (Maastrichtian), Paleocene, Eocene, and Oligocenelower Miocene reservoirs found at depths of $480-3000 \mathrm{~m}$ (Khriachtchevskaia et al., 2009; Stovba et al., 2009). The two largest gas and condensate finds - Golitsyno and Shtormovoe, with recoverable gas or condensate reserves of $420 \mathrm{bcf}$ (bcf) (3 mmboe) and $777 \mathrm{bcf}(21 \mathrm{mmboe})$, respectively - have been developed.

Nedosekova et al. (2008) reviewed the drilled structures and concluded that all the prospects and leads associated with simple four-way closures have been tested. As a general observation, there seems to be a trap-fill issue as the inverted structures could hold much larger hydrocarbon volumes than the discovered resources. The map-view four-way closures of the Golitsyno and Shtormovoe anticlines are 680 and $440 \mathrm{~km}^{2}$, respectively (Sergey Stovba, personal communication, 2010) with multi-trillion cubic feet recoverable gas potential. However, these structures are clearly not filled to spill and the observed gas columns are in the range of tens of meters. The underfilled trap issue can be explained by charge limitations, trap timing versus charge and/or by trap failure or breaching. Given the multiple (up to four) inversional events shaping these anticlines individually, losses to several remigration periods between the inversions probably played a role. These risks also explain why some of the large inverted structures in the area turned out to be dry, like the prominent Gamburtsev anticline (Fig. 10).

There are two schools of thought as to finding more hydrocarbons in this seemingly mature petroleum province. One suggestion was made by Burchell (2008), who described a new gas play type associated with the deeper part of the Golitsyno anticline, beneath the producing lower Paleocene chalks (Fig. 11; Robinson and Kerusov, 1997). Four possible gas-charged Lower Cretaceous sand targets were considered within the rift basin fill of the Karkinit trough at 4500 to $5500 \mathrm{~m}$ depth (Fig. 11). These targets with structural dip in three directions that closes against a fault have a large map-view extent, on the order of about $300 \mathrm{~km}^{2}$. Hydrocarbon charge was deemed to be relatively low risk by Burchell (2008) given the gas-condensate finds in adjacent fields and assuming thick gas-mature Lower Cretaceous shales in between the sand units in the so far undrilled rift basin center. Upper Cretaceous calcareous black shales, as potential source rocks, have been documented on the western part of the Crimean Peninsula (Kitchka et al., 2016). The obvious exploration risks of this deep, inversion-related play include side seal against crystalline basement across the large inverted fault, the presence and quality of the Lower Cretaceous reservoir objectives and trap definition due to the lack of 3D seismic data. This deep play remains untested to date.

The other line of thought is represented by Nedosekova et al. (2008) emphasizing the underexplored nature of stratigraphic and combination traps in the region, such as sand body pinchouts along the flank of paleo-highs. To show the impact of the Eocene inversion events shaping the paleorelief of the basin, we reproduce here the isopach map of the Oligocene to lower Miocene Maykop sequence (Fig. 13; Gozhik et al., 2010). Contrary to what basin-scale well correlations can indicate, incorporating data points from basin highs (Fig. 9) the Maykop isopachs shows dramatic variations between 0 and $1700 \mathrm{~m}$ across the Gulf of Odessa (Fig. 13). Given this range, we interpret a deepwater sedimentary environment for the Karkinit trough.

Whereas the Maykop sequence overall is dominated by shales (Fig. 9), as in the rest of the Black Sea (Tari and Simmons, 2018), there are reservoir quality deepwater sandstones in it, as in the Krymska field (Fig. 13) and in the undeveloped Subbotina oil discovery south of the Kerch Peninsula (Fig. 8), reported by Khriachtchevskaia et al. (2009) and Stovba et al. (2009), respectively. Therefore, we spec- 


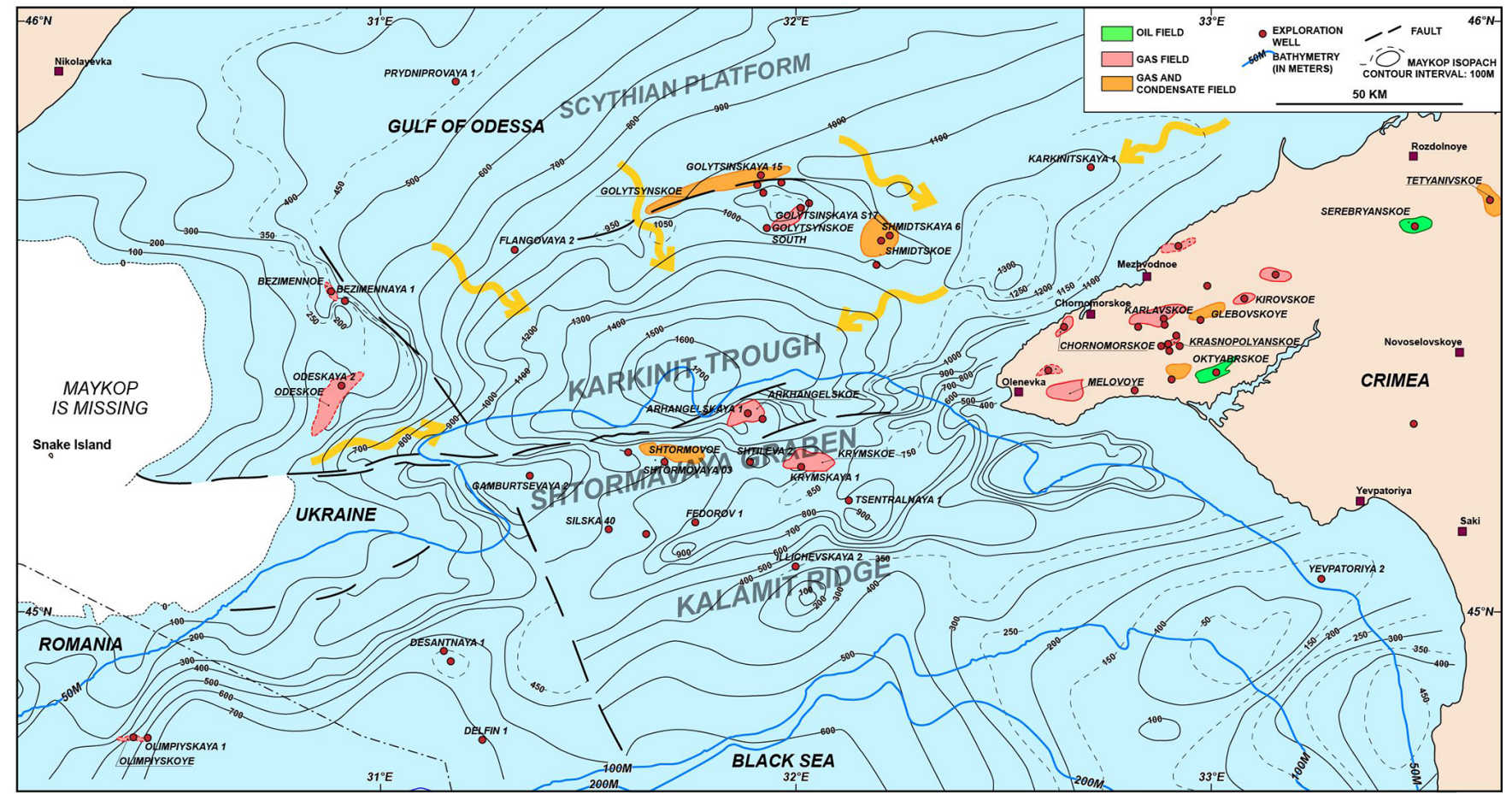

Figure 13. Isopach map of the post-inversion Oligocene to lower Miocene Maykop Suite in the Odessa Shelf, modified from Gozhik (2010). For location, see Fig. 8. Contour intervals are in meters. Note that the thickest Maykop is not captured by the currently available well control (see Fig. 9). The depicted sediment entry points and the deep-water distribution patterns are entirely speculative and are shown here to highlight the stratigraphic trapping potential in the Karkinit basin.

ulate that future regional-scale 3D seismic surveys could image potential longitudinal and transversal intra-Maykop turbiditic systems within the Karkinit trough offering various stratigraphic traps along the basin margin (Fig. 13).

\section{Discussion}

Interesting similarities exist between the tectonostratigraphic evolution of the Western Desert and the western Black Sea (Fig. 3) even if these two areas are located some $2000 \mathrm{~km}$ apart (Fig. 1). Whereas the relative chronology of alternating extensional and compressional periods differs in many respects, several of the distinct inversion events appear to be the same. In particular, the earliest Cretaceous late Cimmerian and late Eocene "Pyrenean" phases correspond to the same intra-plate shortening episodes. Inversion therefore occurred synchronously over many adjacent lithospheric plates. This indicates that horizontal stress transmission occurred through well-coupled plate boundaries, in our case between the African-Arabian, Anatolian, and Eurasian plates. The question then becomes how far a certain peak in the "inter-plate" horizontal stress can reactivate pre-existing extensional fabric and cause detectable structural inversion?

Intuitively, when most or all the plates were in close contact with each other in large continental plate collages like
Gondwana and Pangea, the same intra-plate stress signal could have been transmitted across entire continents and had a "global" impact. This would support the early perception of Stille (1924), who assumed the existence of global orogenic phases. He based his observations mostly on data from Europe and North Africa which could be the expression of intra- or inter-plate stress peaks transmitted across this region throughout most of the Phanerozoic. However, we emphasize that Stille's global phases are misleading in some cases. In particular, the late Cimmerian event in Germany is a Late Jurassic to Early Cretaceous rifting phase that created the Lower Saxony basin (Jonas Kley, personal communication, 2020). Since Stille believed that all unconformities are due to folding or orogenesis (Kley, 2018), he mistakenly correlated the rifting event in Germany with contraction in North Africa.

Regardless, more recently Guiraud (1998) and others (Guiraud et al., 1987; 1992, 2001, 2005; Guiraud and Bellion, 1995; Guiraud and Bosworth, 1997) have similarly documented how precisely both Phanerozoic extension and shortening or inversion events can be correlated across Gondwana and into nearby continental plates.

Another open-ended question relates to the duration of these events. Are these phases, periods, or discrete events? If the horizontal stress peaks are caused by sudden plate movement changes, are they geologically instantaneous, i.e. on the 
(a) Rift Phase 1

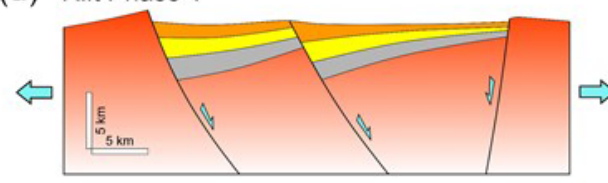

Inversion Phase 1

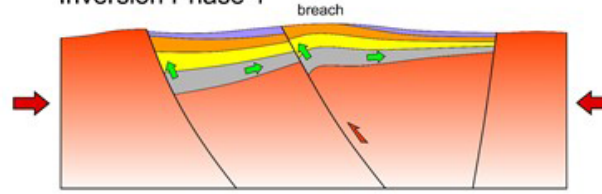

Rift Phase 2

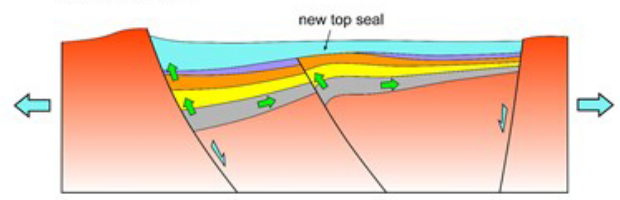

Inversion Phase 2

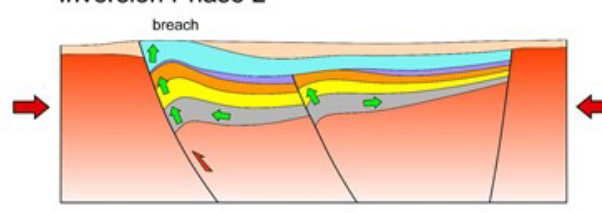

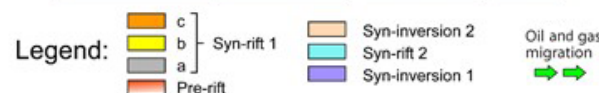

Notes:

Initial rifing with source rocks deposited early
fill history followed by multiple reservorir intervals
(other sequences possible) Scales are only approximate and will vary from system and will vary from system
to system

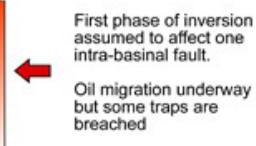
Oil migration underway
but some traps are
breached

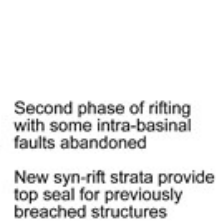
top seal for previously
breached

\section{Second phase of inversion} assumed to affect main
basin bounding fault More breaching of structures that might be sealed by later syn-rift or post-rift
strata Migration pathways can be locally reversed

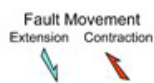

(b) Rift Phase

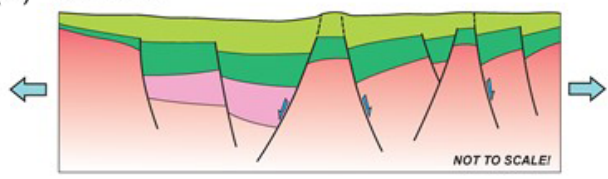

Notes:

Multiple rifting phases with source rocks deposited However, assumed
predecessor Triassic rift basin may be too deep to ate hydrocarbons
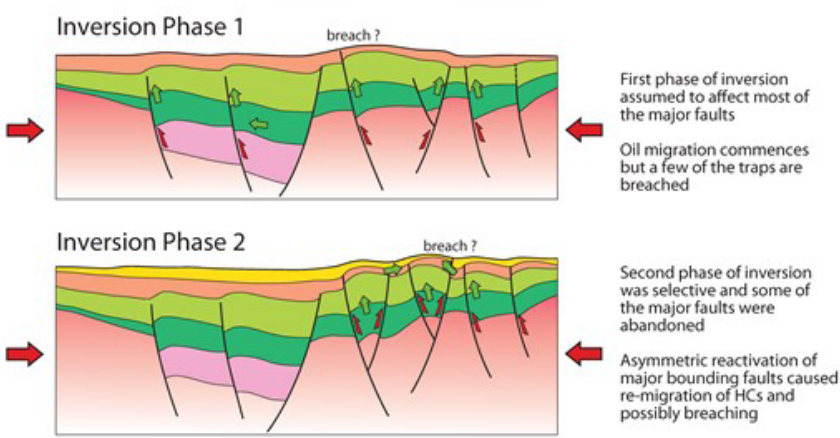

Inversion Phase 3

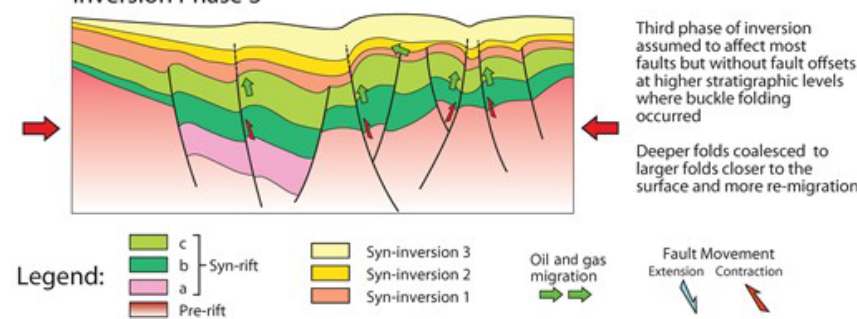

Figure 14. (a) Schematic illustration of some of the possible effects of superimposed, alternating phases of extension and inversion on a rift basin. For simplicity two inversion events are shown affecting different faults, which is commonly observed in the Western Desert of Egypt but will not always be the case. (b) Schematic illustration of a basin in which early extension is followed by multiple phases of inversion. The transect is largely based on observations made in the NW Black Sea, which experienced at least four distinct inversion episodes.

order of $10-100 \mathrm{kyr}$, or more transient in nature, i.e. on the order of $100 \mathrm{kyr}$ to $1 \mathrm{Myr}$ ? The duration and the rate of deformation during these inversion events have direct impact on some of the petroleum system elements of any inverted structure. In the Faghur basin, the duration of the late Cimmerian inversion is less than the present resolution of both paleontologic and thermochronometric dating and probably less than 1 Myr. But the impact of the Santonian event varies widely from sub-basin to sub-basin across the Western Desert with no published quantitative estimates of its duration except that by $66 \mathrm{Ma}$ a younger pulse of shortening can be distinguished. A more tightly constrained understanding of the temporal extent of such inversion events would be very beneficial in any given basin analysis.

The Black Sea inversion structures do differ from those of the Western Desert in several important ways. In the Western Desert, the late Cimmerian and Santonian inversions were separated by several phases of very significant extension-driven subsidence. Inversion in the NW Black Sea was more rapid-fire, quickly superimposed compressional episodes. Also, the ratio of the post-rift (up to the stratigraphic level of the latest significant inversion event) versus syn-rift basin fill is much greater in the Black Sea than in the Western Desert reflecting the evolution of inversion in Mode
II versus Mode I, respectively, sensu Tari et al. (2020). Consequently, the latest Pliocene to neotectonic inversion in the NW Black Sea produced buckle folding of the thick, postrift sedimentary cover instead of the "classic" reverse-fault bounded "Sunda-folds" (Eubank and Makki, 1981) that are more typically observed when the post-rift sequence is still relatively thin at the time of inversion. Earlier Black Sea inversion anticlines with a shorter wavelength were gradually incorporated into longer wavelength folds as the result of the thickening sedimentary cover and the repeated inversional periods. The multiple Black Sea hydrocarbon remigration episodes from older traps to relatively recently formed ones appear to be the main reason for the underfilled or dry nature of most structures in the NW Black Sea basin. Breached and leaky inversion traps are similarly a cause of failure in the Western Desert, but the abundance of pre-inversion sealreservoir pairs has resulted in a higher exploration success rate.

\section{Conclusions}

We have presented an example of a petroliferous basin in which multiple tectonic shortening or inversion events were 
separated in time and stratigraphic position by major extensional rift events - the Western Desert - and one where multiple phases of inversion were superimposed on older, preexisting rift sequences - the NW Black Sea. Other tectonostratigraphic sequences can be imagined, and no two real basins will be identical. Despite the great range of variations that may exist, some general conclusions can be drawn and depicted schematically (Fig. 14). For basins similar to the Western Desert these include (Fig. 14a) the following:

1. Shortening or inversion events that occur early in a basin's extensional history are likely to produce viable traps for hydrocarbons in pre-, syn-, and immediate post-inversion (draping) strata because although some reservoirs may be breached, the structure will be covered and healed by later syn-rift fill. Furthermore, early in the basin history hydrocarbons will not yet generally have started to migrate, so overall loses from the system are minimized.

2. Early inversion events can delay hydrocarbon maturation of underlying pre- or early syn-rift source rocks due to denudation of strata, but only if the inversion is basinscale. This is unlikely to be significant if shortening is mild and reverse movement is restricted to small-offset faults.

3. Inversion, whether early or late, can dramatically impact migration pathways emanating from pre-inversion source rocks. This can occur at the scale of individual fault blocks or entire basins (see further discussion in Bevan and Moustafa, 2012). Given that most extensional basins take the shape of large-scale half grabens, pre-inversion migration will generally be from basin axes up-dip toward the flexural margin. Inversion can re-direct migration toward the faulted margin and fill previously unsourced structures.

4. Late shortening or inversion events will generally have more severe impact on top seal integrity because there is less chance for post-inversion deposition of new top seals.

For basins with histories more like the NW Black Sea (Fig. 14b), the following apply:

1. Early inversion events following a prolonged period of multiple rifting episodes are likely to produce traps which could by charged by initial hydrocarbon generation from deeper syn-rift units. Most of the pre-existing normal faults tend to reactivate to accommodate inversion across the sub-basins.

2. Repeated episodes of inversion tend to be selective and only segments of the basin will experience reverse fault movements along pre-existing fault planes. These can enhance the already existing traps and cause additional remigration of hydrocarbons but can cause partial leakage or total breaching of some of the early traps.

3. Ongoing inversion can reconfigure the basin-scale geometry by creating new depocenters where syninversion reservoirs can develop. The selective reactivation of favorably oriented major faults may result in a polarity switch within sub-basins causing remigration and further loss of hydrocarbons. This explains the underfilled nature of most accumulations with otherwise valid traps.

4. Repeated episodes of mild to moderate inversion where erosion does not remove strata over the growing structures can result in significant thickness of syn-inversion sediments. In this case, the contractionally reactivated syn-rift normal faults cannot propagate through the entire post-rift basin fill and, therefore, the risk associated with breaching becomes less critical. Some of the deeper inversion-related traps may even receive new hydrocarbon charge from regional post-rift source rocks. The presence of buckle folds at higher stratigraphic levels is typical for Mode II inversion structures where the post-rift sequence is thicker than the syn-rift basin fill of the underlying extensional structure (Tari et al., 2020).

Data availability. Some of the seismic lines used in this study are confidential and not available publicly.

Author contributions. WB and GT wrote the text, prepared the figures, and compiled the paper.

Competing interests. The authors declare that they have no conflict of interest.

Special issue statement. This article is part of the special issue "Inversion tectonics - 30 years later". It is not associated with a conference.

Acknowledgements. We thank Jonas Kley and Piotr Krzywiec for inviting us to contribute this paper to the special issue of Solid Earth and for their editorial efforts. Discussions concerning inversion tectonics with Albert Bally, René Guiraud, Ahmed El-Hawat, Daniel Helgeson, Oxana Khriachtchevskaia, Alexander Kitchka, Andrew Robinson, Daniel Stockli, and Sergiy Stovba are greatly appreciated. Dubravko Lučić, Csaba Krézsek, and Jonas Kley kindly reviewed the paper for Solid Earth. The PSDM seismic section in the Gulf of Odessa is courtesy of ION and it is gratefully acknowledged. We thank Apache Egypt Companies and OMV for permission to publish this paper. 
Review statement. This paper was edited by Piotr Krzywiec and reviewed by Dubravko Lucic, Csaba Krézsek, and Jonas Kley.

\section{References}

Abadi, A. M., van Wees, J.-D., van Dijk, P. M., and Cloetingh, S. A. P. L.: Tectonics and subsidence evolution of the Sirt Basin, Libya, AAPG Bull., 92, 993-1027, https://doi.org/10.1306/03310806070, 2008.

Abbas, I., Guinn, S., Afify, W., Ramadan, Y., Jennette, D., and Gharieb, A.: Impact of Jurassic volcanic rocks on hydrocarbon exploration, North Western Desert, Egypt, 14th Offshore Mediterranean Conference and Exhibition, Ravena, Italy, extended abstract, 2019.

Abd El-Aziz, M., Moustafa, A. R., and Said, S. E.: Impact of basin inversion on hydrocarbon habitat in the Qarun concession, Western Desert, Egypt, in: Proceedings of the 14th EGPC Petroleum Conference, 139-155, 1998.

Abdelbaset, M., Bosworth, W., Versfelt, J., and Sehim, A.: JurassicCretaceous rift development: West Kalabsha, Faghur Basin, Western Desert (Egypt), Geol. Soc. Egypt Ann. Meet., 2019.

Abdel Khalek, M. L., El Sharkawi, M. A., Darwish, M., Hagras, M., and Sehim, A.: Structural history of Abu Roash district, Western Desert, Egypt, J. Afr. Earth Sci., 9, 435-443, https://doi.org/10.1016/0899-5362(89)90027-4, 1989.

Alaygut, D., Teymur, S., Seker, H., Akoz, O., Oner, A., and Sarginalp, M.: Depositional model and reservoir features of the Eocene sandstones in the Akcakoca area: West Black Sea region, Turkey, AAPG Search and Discovery \#90024, 2004.

Bally, A. W.: Tectogénèse et sismique réflexion, Bulletin de la Société géologique de France, Serie 7, 29, 279-285, 1984.

Berra, F. and Angiolini, L.: The evolution of the Tethys region throughout the Phanerozoic: A brief tectonic reconstruction, in: Petroleum systems of the Tethyan region, edited by: Marlow, L., Kendall, C., and Yose, L., AAPG Memoir 106, 1-27, https://doi.org/10.1306/13431840m1063606, 2014.

Bergerat, F., Vangelov, D., and Dimov, D.: Brittle deformation, palaeostress field reconstruction and tectonic evolution of the Eastern Balkanides (Bulgaria) during Mesozoic and Cenozoic times, in: Sedimentary Basin Tectonics from the Black Sea and Caucasus to the Arabian Platform, edited by: Sosson, M., Kaymakci, N., Stephenson, R. A., Bergerat, F., and Starostenko, V., Geol. Soc. Lond. Spec. Publ., 340, 77-111, https://doi.org/10.1144/sp340.6, 2010.

Bevan, T. G. and Moustafa, A. R.: Inverted rift-basins of northern Egypt, in: Regional Geology and Tectonics: Phanerozoic Passive Margins, Cratonic Basins and Global Tectonic Maps, edited by: Roberts, D. G. and Bally, A. W., Elsevier, Amsterdam, 483-507, https://doi.org/10.1016/b978-0-444-56356-9.00018-3, 2012.

Bosworth, W.: Mesozoic and early Tertiary rift tectonics in East Africa. Tectonophysics, 209, 115-137, https://doi.org/10.1016/0040-1951(92)90014-w, 1992.

Bosworth, W., El-Hawat, A. S., Helgeson, D. E., and Burke, K.: Cyrenaican "shock absorber" and associated inversion strain shadow in the collision zone of northeast Africa, Geology, 36, 695-698, https://doi.org/10.1130/g24909a.1, 2008.

Bosworth, W., Stockli, D. F., and Helgeson, D. E.: Integrated outcrop, 3D seismic, and geochronologic interpretation of Red Sea dike-related deformation in the Western Desert, Egypt - the role of the 23 Ma Cairo "mini-plume", J. Afr. Earth Sci., 109, 107119, https://doi.org/10.1016/j.jafrearsci.2015.05.005, 2015a.

Bosworth, W., Drummond, M., Abrams, M., and Thompson, M.: Jurassic rift initiation source rock in the Western Desert, Egypt - relevance to exploration in other continental rift systems, in: Petroleum Systems in "Rift" Basins, edited by: Post, P. J., Coleman Jr., J. L., Rosen, N. C., Brown, D. E., Roberts-Ashby, T., Kahn, P., and Rowan, M., 34th Annual GCSSEPM Foundation Perkins-Rosen Research Conference, 13-16 December 2015, Houston, CD-ROM, 615-650, https://doi.org/10.5724/gcs.15.34.0615, 2015b.

Buchanan, J. G. and Buchanan, P. G.: Basin Inversion, J. Geol. Soc. Lond. Spec. Publ., 88, 596 pp., ISBN-13 978-1-8977-9929-1, 1995.

Burchell, M.: Ukrainian upstream offshore developments. Paper presented at the Balkan Black Sea Petroleum 14th Annual Conference, Budapest, 8-9 April, 2008.

Burke, K. and Dewey, J. F.: Two plates in Africa during the Cretaceous?, Nature, 249, 313-316, https://doi.org/10.1038/249313a0, 1974.

Cooper, M. A. and Williams, G. D.: Inversion tectonics, J. Geol. Soc. Lond. Spec. Publ., 44, 375 pp., 1989.

Cooper, M. A. and Warren, M. J.: The geometric characteristics, genesis and petroleum significance of inversion structures, in: Continental Tectonics and Mountain Building: The Legacy of Peach and Horne, edited by: Law, R. D., Butler, R. W. H., Holdsworth, R. E., Krabbendam, M., and Strachan, R. A., Geol. Soc. Lond. Spec. Publ., 335, 827-846, https://doi.org/10.1144/sp335.33, 2010.

Dewey, J. F., Helman, M. L., Turco, E., Hutton, D. H. W., and Knott, S. D.: Kinematics of the western Mediterranean, in.: Alpine tectonics, edited by: Coward, M. P., Dietrich, D., and Park, R. G., Geol. Soc. Lond. Spec. Publ., 45, 265-283, 1989.

Dinu, C., Wong, H. K., Tambrea, D., and Matenco, L.: Stratigraphic and structural characteristics of the Romanian Black Sea shelf, Tectonophysics, 410, 417-435, https://doi.org/10.1016/j.tecto.2005.04.012, 2005.

Doglioni, C., Busatta, C., Bolis, G., Marianini, L. and Zanella, M.: Structural evolution of the eastern Balkans (Bulgaria), Mar. Pet. Geol., 13, 225-251, https://doi.org/10.1016/02648172(95)00045-3, 1996.

El Gazzar, A. M., Moustafa, A. R., and Bentham, P.: Structural evolution of the Abu Gharadig field area, Northern Western Desert, Egypt, J. Afr. Earth Sci., 124, 340-354, https://doi.org/10.1016/j.jafrearsci.2016.09.027, 2016.

Eubank, R. T. and Makki, A. C.: Structural geology of the central Sumatra back-arc basin. Indonesian Petroleum Association, 10th Ann Convention, 153-196, 1981.

Finetti, I., Bricchi, G., Del Ben, A., Pipan, M., and Xuan, Z.: Geophysical study of the Black Sea area, in: Monograph on the Black Sea, edited by: Finetti, I., Bolletino di Geofisica Teorica ed Applicata, 30, 117- 118, 197-324, 1988.

Garfunkel, Z.: Origin of the Eastern Mediterranean basin: a reevaluation, Tectonophysics, 391, 11-34, https://doi.org/10.1016/j.tecto.2004.07.006, 2004.

Glennie, K. W. and Boegner, P. L. E.: Sole Pit inversion tectonics, in: Petroleum Geology of the Continental Shelf of North- 
west Europe, edited by: Illing, L. V. and Hobson, G. D., Institute of Petroleum, London, 110-120, 1981.

Gozhik, P. F., Maslun, N. V., Plotnikova, L. F., Ivanik, M. M., and Yakuschin, L. M.: The Stratigraphy of Meso-Cenozoic Deposits of the Black Sea Northwestern Shelf, Geol. Institute, Kiev, Ukraine, 170 pp., 2006.

Gozhik, P. F., Maslun, N. V., Boiciskhy, Z. I., Ivanik, M. M., and Khlushina, G. V.: Regional Cenozoic stratigraphy of the PreKerch shelf and the Eastern Black Sea Basin, Geol. J. Natl. Acad. Sci. Ukraine, 1, 7-41, 2010 (in Ukrainian with English abstract).

Guiraud, R.: Mesozoic rifting and basin inversion along the northern African Tethyan margin: an overview, in: Petroleum Geology of North Africa, edited by: Macgregor, D., Moody, R. T. J., and Clark-Lowes, D. D., Geol. Soc. Lond. Spec. Publ., 132, 217-229, https://doi.org/10.1144/gsl.sp.1998.132.01.13, 1998.

Guiraud, R. and Bellion, Y.: Late Carboniferous to Recent geodynamic evolution of the West Gondwanian cratonic Tethyan margins, in: The Ocean Basins and Margins 8, the Tethys Ocean, edited by: Nairn, A., Ricou, L. E., Vrielynck, B., and Dercourt, J., Plenum Press, New York, 101-124, https://doi.org/10.1007/9781-4899-1558-0_3, 1995.

Guiraud, R. and Bosworth, W.: Senonian basin inversion and rejuvenation of rifting in Africa and Arabia: synthesis and implications to plate-scale tectonics, Tectonophysics, 282, 39-82, https://doi.org/10.1016/s0040-1951(97)00212-6, 1997.

Guiraud, R. and Bosworth, W.: Phanerozoic geodynamic evolution of northeastern Africa and the northwestern Arabian platform, Tectonophysics, 315, 73-108, https://doi.org/10.1016/s00401951(99)00293-0, 1999.

Guiraud, R., Bellion, Y., Benkhelil, J., and Moreau, C.: PostHercynian tectonics in Northern and Western Africa, in: African Geology Reviews, edited by: Bowden, P. and Kinnaird, J. A., Geol. J., 22, 433-466, https://doi.org/10.1002/gj.3350220628 , 1987.

Guiraud, R., Binks, R. M., Fairhead, J. D., and Wilson, M.: Chronology and geodynamic setting of Cretaceous-Cenozoic rifting in West and Central Africa, Tectonophysics, 213, 227-234, 1992.

Guiraud, R., Issawi, B., and Bosworth, W.: Phanerozoic history of Egypt and surrounding areas, in: Peri-Tethys Memoir 6: PeriTethyan Rift/Wrench Basins and Passive Margins, edited by: Ziegler, P. A., Cavazza, W., Robertson, A. H. F., and CrasquinSoleau, S., Mémoires du Muséum national d'Histoire naturelle de Paris, 186, 469-509, 2001.

Guiraud, R., Bosworth, W., Thierry, J., and Delplanque, A.: Phanerozoic geological evolution of Northern and Central Africa: an overview, in: Phanerozoic evolution of Africa, edited by: Catuneanu, O., Guiraud, R., Eriksson, P., Thomas, B., Shone, R., and Key, R., J. Afr. Earth Sci., 43, 83-143, https://doi.org/10.1016/j.jafrearsci.2005.07.017, 2005.

Hippolyte, J.-C.: Geodynamics of Dobrogea (Romania): new constraints on the evolution of the Tornquist-Teisseyre Line, the Black Sea and the Carpathians, Tectonophysics, 357, 33-35, https://doi.org/10.1016/s0040-1951(02)00361-x, 2002.

Hippolyte, J. C., Murovskaya, A., Volfman, Y., Yegorova, T., Gintov, O., Kaymakci, N., and Sangu, E.: Age and geodynamic evolution of the Black Sea Basin: Tectonic evidences of rifting in Crimea, Mar. Pet. Geol., 93, 298-314, https://doi.org/10.1016/j.marpetgeo.2018.03.009, 2018.
Kerdany, M. T. and Cherif, O. H.: Mesozoic, chap. 22, in: The Geology of Egypt, edited by: Said, R. and Balkema, A. A., Rotterdam, the Netherlands, 407-438, 1990.

Jarvis, A., Reuter, H. I., Nelson, A., and Guevara, E.: Hole-filled seamless SRTM data V4, International Centre for Tropical Agriculture (CIAT), available at: http://srtm.csi.cgiar.org (last access: 9 October 2020), 2008.

Khriachtchevskaia, O., Stovba, S., and Popadyuk, I.: Hydrocarbon prospects in the Western Black Sea of Ukraine, The Leading Edge, 28, 260-264, https://doi.org/10.1190/1.3236371, 2009.

Khriachtchevskaia, O., Stovba S., and Stephenson R.: CretaceousNeogene tectonic evolution of the northern margin of the Black Sea from seismic reflection data and tectonic subsidence analysis, in: Sedimentary Basin Tectonics from the Black Sea and Caucasus to the Arabian Platform, edited by: Sosson, M., Kaymakci, N., Stephenson, R., Bergerat, F., and Starostenko, V., Geol. Soc. Lond. Spec. Publ., 340, 137-157, https://doi.org/10.1144/sp340.8, 2010.

Keeley, M. L. and Wallis, R. J.: The Jurassic system in Northern Egypt: II. Depositional and tectonic regimes, J. Petrol. Geol., 14, 49-64, https://doi.org/10.1306/bf9ab6d8-0eb6-11d78643000102c1865d, 1991.

Keeley, M. L., Dungworth, G., Floyd, C. S., Forbes, G. A., King, C., McGarva, R. M., and Shaw, D.: The Jurassic System in northern Egypt: I. Regional stratigraphy and implications for hydrocarbon prospectivity, J. Petrol. Geol., 13, 397-420, 1990.

Kitchka, A., Ishchenko, I., and Bashirov, G.: Cenomanian-Turonian calcareous black shales of the Tarkhankut Peninsula as a potential unconventional hydrocarbon shale gas play, AAPG Europe Regional Conference, Bucharest, 19-20 May, 2016.

Kley, J.: Hans Stille in Göttingen, Global Tectonics and Metallogeny, 10, 61-65, https://doi.org/10.1306/bf9ab6d1-0eb6-11d7$8643000102 \mathrm{c} 1865 \mathrm{~d}, 2018$.

Kley, J. and Krzywiec, P.: Inversion tectonics 30 years later - an introduction, Solid Earth, this issue, 2020.

Krezsek, C., Bercea, R. I., Tari, G., and Ionescu, G.: Cretaceous sedimentation along the Romanian margin of the Black Sea: inferences from onshore to offshore correlations, in: Petroleum Geology of the Black Sea, edited by: Simmons, M. D., Tari, G. C., and Okay, A. I., Geol. Soc. Lond. Spec. Publ., 464, 211-245, https://doi.org/10.1144/sp464.10, 2017.

Lamplugh, G. W.: Structure of the Weald and analogous tracts, Q. J. Geol. Soc. Lond., 75, LXXIII-XCV, 1919.

Le Pichon, X., Bergerat, F., and Roulet, M.-J.: Plate kinematics and tectonics leading to the Alpine belt formation; a new analysis, Geol. Soc. Amer. Spec. Paper, 218, 111-131, https://doi.org/10.1130/spe218-p111, 1988.

Longacre, M., Bentham, P., Hanbal, I., Cotton, J., and Edwards, R.: New crustal structure of the Eastern Mediterranean basin: detailed integration and modeling of gravity, magnetic, seismic refraction, and seismic reflection data, EGM 2007 International Workshop, Capri, Italy, 2007.

McHargue, T. R., Heidrick, T. L., and Livingston, J. E.: Tectonostratigraphic development of the interior Sudan rifts, Central Africa, Tectonophysics, 213, 187-202, https://doi.org/10.1016/b978-0-444-89912-5.50037-5, 1992.

Macgregor, D. S.: Hydrocarbon habitat and classification of inverted rift basins, in: Basin Inversion, edited by: Buchanan, J. G. 
and Buchanan, P. G., Geol. Soc., Lond. Spec. Publ., 88, 83-93, https://doi.org/10.1144/gsl.sp.1995.088.01.06, 1995.

Meneisy, M. Y.: Vulcanicity, in: The Geology of Egypt, edited by: Said, R. and Balkema, A. A., chap. 9, Rotterdam, the Netherlands, 157-172, 1990.

Menlikli, C., Demirer, A. Sipahioğlu, Ö., Körpe, K. and Aydemir, V.: Exploration plays in the Turkish Black Sea, The Leading Edge, 28, 1066-1075, https://doi.org/10.1190/1.3236376, 2009.

Metwalli, M. H. and Abd El-Hady, Y. E.: Petrographic characteristics of oil-bearing rocks at Alamein oil field; significance in source-reservoir relations in northern Western Desert, Egypt, AAPG Bull., 59, 510-523, https://doi.org/10.1306/83d91cbd16c7-11d7-8645000102c1865d, 1975.

Morosanu, I.: Inverted structural types of the Romanian offshore (Black Sea), in: Geology and Tectonics of the Romania Black Sea Shelf and its Hydrocarbon Potential, edited by: Dinu, C. and Mocanu, V., Bucharest Geoscience Forum Spec., Bucharest, 2, 21-28, 2002.

Moustafa, A. R.: Wrench tectonics in the north Western Desert of Egypt (Abu Roash area, southwest of Cairo), Middle East Research Centre, Ain Shams University, Earth Sci. Series, 2, 1-16, 1988.

Moustafa, A. R. and Khalil, M. H.: Superposed deformation in the northern Suez Rift, Egypt: relevance to hydrocarbon exploration, J. Petrol. Geol., 18, 245-266, https://doi.org/10.1306/bf9ab7580eb6-11d7-8643000102c1865d, 1995.

Moustafa, A. R., El-Badrawy, R., and Gibali, H.: Pervasive E-ENE oriented faults in northern Egypt and their effect on the development and inversion of prolific sedimentary basins, Proceedings 14th Petroleum Conference, EGPC, Cairo, 1, 51-67, 1998.

Moustafa, A. R., Saoudi, A., Moubasher, A., Ibrahim, I.M., Molokhia, H., and Schwartz, B.: Structural setting and tectonic evolution of the Bahariya Depression, Western Desert, Egypt, GeoArabia, 8, 91-124, 2003.

Murovskaya, A., Hippolyte, J. C., Sheremet, E., Egorova, T., Volfman, Y., and Kolesnikova, E.: Deformation structures and stress field of the south-western Crimea in the context of the evolution of western Black Sea Basin, Geodinamika, 2, 53-68, 2014.

Murovskaya, A., Hippolyte, J. C., Sheremet, Y., and Yegorova, T.: Recent and paleo-stresses at the northern margin of the Black Sea and the Crimea Mountain in Meso-Cenozoic-Quarternary (according to mechanisms of earthquakes foci and field tectonophysical data), Geofizicheskiy Zhurnal, 40, 44-69, 2018 (in Russian).

Nedosekova, I. V., Karpenko, I. V., and Starchenko, G. S.: Promising Hydrocarbon Prospects in the Paleogene Formations of the Black Sea Northwestern Shelf, Ukraine, EAGE International Conference on Petroleum Geology and Hydrocarbon Potential of Caspian and Black Sea Regions, Baku, Azerbaijan, 6-8 October, 2008.

Nikishin, A. M., Ziegler, P. A., Panov, D. I., Nazarevich, B. P., and Brunet, M. F.: Mesozoic and Cainozoic evolution of the Scythian platform-Black Sea-Caucasus domain, Mémoires du Muséum national d'histoire naturelle, 186, 295-346, 2001.

Nikishin, A. M., Korotaev, M. V., Ershov, A. V., and Brunet, M.-F.: The Black Sea basin: tectonic history and Neogene-Quaternary rapid subsidence modeling, Sediment. Geol., 156, 149-168, 2003.
Nikishin, A. M., Khotylev, A. O., Bychkov, A. Yu, Kopaevich, L. F., Petrov, E. I., and Yapaskurt, V. O.: Cretaceous volcanic belts and the Black Sea Basin history, Mosc. Univ. Geol. Bull., 68, 141-154, 2013.

Nikishin, A. M., Okay, A. I., Tüysüz, O., Demirer, A., Amelin, N., and Petrov, E.: The Black Sea basins structure and history: new model based on new deep penetration regional seismic data, Part 1: Basins structure and fill, Mar. Pet. Geol., 59, 638-655, https://doi.org/10.1016/j.marpetgeo.2014.08.017, 2015a.

Nikishin, A. M., Okay, A., Tüysüz, O., Demirer, A., Wannier, M., Amelin, N., and Petrov, E.: The Black Sea basins structure and history: New model based on new deep penetration regional seismic data, Part 2: Tectonic history and paleogeography, Mar. Pet. Geol., 59, 656-670, https://doi.org/10.1016/j.marpetgeo.2014.08.018, 2015b.

Norton, P.: Rock stratigraphic nomenclature of the Western Desert, Egypt, Gulf of Suez Petroleum Company internal report, 18 pp., 1967.

Ogg, J. G., Ogg, G. M., and Gradstein, F. M.: A Concise Geologic Time Scale, Elsevier B. V., Amsterdam, the Netherlands, 234 pp., https://doi.org/10.1016/B978-0-444-59467-9.00001-7, 2016.

Okay, A. I. and Nikishin, A. M.: Tectonic evolution of the southern margin of Laurasia in the Black Sea region, Int. Geol. Rev., 57, 1051-1076, https://doi.org/10.1080/00206814.2015.1010609, 2015.

Okay, A. I. and Tüysüz, O.: Tethyan sutures of northern Turkey, in: The Mediterranean Basins: Tertiary Extension within the Alpine Orogen, edited by: Durand, B., Jolivet, L., Horváth, F., and Séranne, M., Geol. Soc. Lond. Spec. Publ., 156, 475-515, https://doi.org/10.1144/gsl.sp.1999.156.01.22, 1999.

Panek, T., Danišík, M., Hradecký, J., and Frisch, W.: Morphotectonic evolution of the Crimean mountains (Ukraine) as constrained by apatite fission track data, Terra Nova, 21, 271-278, https://doi.org/10.1111/j.1365-3121.2009.00881.x, 2009.

Popov, S. V., Antipov, M. P., Zastrozhnov, A. S., Kurina, E. E., and Pinchuk, T. N.: Sea-level fluctuations on the north shelf of the Eastern Paratethys in the Oligocene-Neogene, Strat. Geol. Correlation, 18, 200-224, https://doi.org/10.1134/s0869593810020073, 2010.

Robinson, A. G.: Regional and Petroleum Geology of the Black Sea and Surrounding Region, AAPG Memoir, 68, 385 pp., https://doi.org/10.1306/m68612, 1997.

Robinson, A. G. and Kerusov, E.: Stratigraphic and structural development of the Gulf of Odessa, Ukrainian Black Sea: implications for petroleum explorations, in: Regional and Petroleum Geology of the Black Sea and Surrounding Region, edited by: Robinson, A. G., AAPG Memoir, 68, 369-380, https://doi.org/10.1306/m68612c19, 1997.

Robinson, A. G., Spadini, G., and Cloetingh, S.: Stratigraphic evolution of the Black Sea: inferences from basin modelling, Mar. Pet. Geol., 12, 821-836, https://doi.org/10.1016/02648172(95)98850-5, 1995.

Robinson, A. G., Rudat, J. H., Banks, C. J., and Wiles, R. L. F.: Petroleum geology of the Black Sea, Mar. Pet. Geol., 13, 195223, https://doi.org/10.1016/0264-8172(95)00042-9, 1996.

Said, R.: The Geology of Egypt, Elsevier, Amsterdam, the Netherlands, 377 pp., 1962.

Saintot, A., Stephenson, R. A., Stovba, S., Brunet, M.-F., Yegorova, T., and Starostenko, V.: The evolution of the southern margin 
of eastern Europe (Eastern European and Scythian platforms) from the latest Precambrian-Early Palaeozoic to the Early Cretaceous, in: European Lithosphere Dynamics, edited by: Gee, D. and Stephenson, R. A., Geol. Soc. Lond. Memoirs, 32, 481-505, https://doi.org/10.1144/gsl.mem.2006.032.01.30, 2006.

Savostin, L. A., Sibuet, J.-C., Zonenshain, L. P., Le Pichon, X., and Roulet, M.-J.: Kinematic evolution of the Tethys belt from the Atlantic Ocean to the Pamirs since the Triassic, Tectonophysics, 123, 1-35, https://doi.org/10.1016/00401951(86)90192-7, 1986.

Schull, T. J.: Rift basins of interior Sudan: petroleum exploration and discovery, AAPG Bull., 72, 11281142, https://doi.org/10.1306/703c9965-1707-11d78645000102c1865d, 1988.

Şengör, A. M. C.: Mid-Mesozoic closure of Permo-Triassic Tethys and its implications, Nature, 279, 590-593, https://doi.org/10.1038/279590a0, 1979.

Sheremet, Y., Sosson, M., Gintov, O., Muller, C., Yegorova, T., and Murovskaya, A.: Key problems of stratigraphy in the Eastern Crimea Peninsula, some insights from new dating and structural data, in: Tectonic Evolution of the Eastern Black Sea and Caucasus, edited by: Sosson, M., Stephenson, R. A., and Adamia, S. A., Geol. Soc. Lond. Spec. Publ., 428, 265-306, https://doi.org/10.1144/sp428.14, 2016a.

Sheremet, Y., Sosson, M., Ratzov, G., Sydorenko, G., Voitsitskiy, Z., Yegorova, T., Gintov, O., and Murovskaya, A.: An offshore-onland transect across the north-eastern Black Sea basin (Crimean margin): Evidence of Paleocene to Pliocene two-stage compression, Tectonophysics, 688, 84-100, https://doi.org/10.1016/j.tecto.2016.09.015, 2016b.

Stampfli, G. M., Mosar, J., Favre, P., Pillevuit, A., and Vannay, J. C.: Permo-Mesozoic evolution of the western Tethys realm: the Neo-Tethys East Mediterranean Basin connection, in: PeriTethys Memoir 6: Peri-Tethyan Rift/Wrench Basins and Passive Margins, edited by: Ziegler, P. A., Cavazza, W., Robertson, A. H. F., and Crasquin-Soleau, S., Mémoires du Muséum National d'Histoire Naturelle de Paris, 186, 51-108, 2001.

Stephenson, R. A. and Schellart, W.: The Black Sea back-arc basin: insights to its origin from geodynamic models of modern analogues, in: Sedimentary Basin Tectonics from the Black Sea and Caucasus to the Arabian Platform, edited by: Sosson, M., Kaymakci, N., Stephenson, R. A., Bergerat, F., and Starostenko, V., Geol. Soc. Lond. Spec. Publ., 340, 11-21, https://doi.org/10.1144/sp340.2, 2010.

Stille, H.: Grundfragen der vergleichenden Tektonik, Gebrüder Borntraeger, 443 pp., 1924.

Stovba, S., Khriachtchevskaia, O., and Popadyuk, I.: Hydrocarbon-bearing areas in the eastern part of the Ukrainian Black Sea, The Leading Edge, 28, 1042-1045, https://doi.org/10.1190/1.3236373, 2009.

Stovba, S. M., Khriachtchevskaia, O. I., and Popadyuk I. V.: Crimea and Ukrainian Eastern Black Sea Basin as an inverted Early Cretaceous rift system, in: Abstracts of Darius Programme, Eastern Black Sea - Caucasus Workshop, edited by: Sosson, M. and Adamia, S. H., 24-25 June 2013, Tbilisi, Georgia, 65-67, 2013.
Stovba, S. M., Popadyuk, I. V., Khriachtchevskaia, O. I., and Fenota, P. O.: The Ukrainian Sector of the Black Sea and Crimea: the origin, tectonics and evolution, in: 16th International Conference on Geoinformatics-Theoretical and Applied Aspects, 2017, 1-5, European Association of Geoscientists and Engineers, 2017.

Tari, G.: Is the Black Sea really a back-arc basin?, Transactions of the GCSEPM Foundation Perkins - Rosen 34th Annual Research Conference "Petroleum Systems in Rift Basins", 510520, https://doi.org/10.5724/gcs.15.34.0509, 2015.

Tari, G., Fallah, M., Kosi, W., Schleder, Z., Turi, V., and Krezsek, C.: Regional rift structure of the Western Black Sea Basin: mapview kinematics, in: Petroleum Systems in Rift Basins, 34th Annual GCSEPM Foundation Perkins - Rosen Research Conference, 372-395, https://doi.org/10.5724/gcs.15.34.0372, 2015.

Tari, G., Arbouille, D., Schleder, Z., and Toth, T.: Inversion tectonics: a brief petroleum industry perspective, Solid Earth, 11, 865-1889, https://doi.org/10.5194/se-11-1865-2020, 2020.

Tari, G. C. and Simmons, M. D.: History of deepwater exploration in the Black Sea and an overview of deepwater petroleum play types, in: Petroleum Geology of the Black Sea, edited by: Simmons, M. D., Tari, G. C., and Okay, A. I., Geol. Soc. Lond. Spec. Publ., 464, 439-475, https://doi.org/10.1144/sp464.16, 2018.

Tsereteli, N., Tibaldi, A., Alania, V., Gventsadse, A., Enukidze, O., Varazanashvili, O., and Müller, B. I. R.: Active tectonics of central-western Caucasus, Georgia, Tectonophysics, 691, 328344, https://doi.org/10.1016/j.tecto.2016.10.025, 2016.

Turner, J. P. and Williams, C. A.: Sedimentary basin inversion and intra-plate shortening, Earth-Sci. Rev., 65, 277-304, https://doi.org/10.1016/j.earscirev.2003.10.002, 2004.

Vernyhorova, Y. V. and Ryabokon, T. S.: The stratigraphy of the Oligocene-lower Miocene deposits of southern Ukraine, Turkish J. Earth Sci., 29, 170-207, https://doi.org/10.3906/yer-1905-24, 2020.

Wennekers, J. H. N., Wallace, F. K., and Abugares, Y. I.: The geology and hydrocarbons of the Sirt Basin: a synopsis, in: The geology of the Sirt Basin, edited by: Salem, M. J., Mouzughi, A. J., and Hammuda, O. S., Elsevier, Amsterdam, Vol. 1, 3-56, 1996.

Williams, G. D., Powell, C. M., and Cooper, M. A.: Geometry and kinematics of inversion tectonics, in: Inversion Tectonics, edited by: Cooper, M. A. and Williams, G. D., Geol. Soc. Lond. Spec. Publ., 44, 3-15, https://doi.org/10.1144/gsl.sp.1989.044.01.02, 1989.

Yousef, M., Moustafa, A. R., Bosworth, W., and Helgeson, D.: Structural and tectonic evolution of East Bahariya concession, northern Western Desert, Egypt, Egyptian J. Geol., 54, 1-16, 2010.

Yousef, M., Yousef, M., and Sehim, A., Structural style and evolution of inversion structures of Horus field, Alamein Basin, northern Western Desert of Egypt, Mar. Pet. Geol., 110, 55-72, https://doi.org/10.1016/j.marpetgeo.2019.07.009, 2019. 